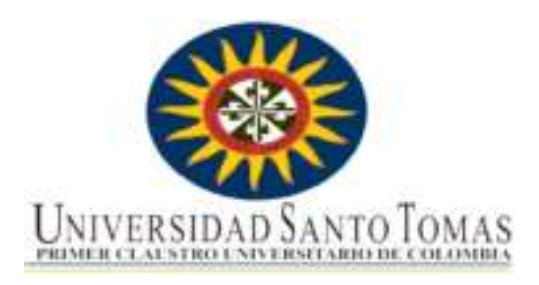

\title{
Territorio y cultura: factores claves en la construcción de los contextos escolares. El caso del Programa Félix y Susana
}

\section{Julia María Correa Upegui}

Universidad Santo Tomás

Maestría en Comunicación, Desarrollo y Cambio Social

Bogotá, Colombia

2017 



\title{
Territorio y cultura: factores claves en la construcción de los contextos escolares. El caso del Programa Félix y Susana
}

\author{
Julia María Correa Upegui
}

Trabajo de investigación presentado como requisito parcial para optar al título de:

Magister en Comunicación, Desarrollo y Cambio Social

Directora:

Mg. Sonia Uruburu Gilède

Línea de Investigación:

Comunicación, salud, medio ambiente y sostenibilidad

Universidad Santo Tomás

Facultad de Comunicación Social

Bogotá, Colombia

2017 

A mis hijas, por prestarme su tiempo 



\section{Resumen}

Cada territorio tiene un sinnúmero de características culturales que obligan a pensar y repensar el papel de los programas de carácter nacional que se implementan en diferentes regiones de un mismo país. Los territorios y sus culturas no se pueden mirar en blanco y negro, es necesario poder leer los tonos grises que los conforman y los hacen particulares; cuanto mejor se lean las realidades y sus contextos, se podrán plantear mejores iniciativas que respondan a una transformación social y propuestas comunicativas efectivas y pertinentes. Esta investigación etnográfica de observación participante se acerca a las características culturales que influyen en la construcción de los contextos escolares y por ende en los procesos educativos de dos instituciones educativas: Camino de Paz en el barrio Villa Liliam de la Comuna 8 de Medellín, y Benkos Bioho en San Basilio de Palenque, Bolívar; donde se implementan Félix y Susana, programa de educación en sana convivencia liderado por la Fundación SURA.

Los resultados de esta investigación prenden las alarmas sobre el estado de abandono en el que crecen los niños y niñas del país, y se convierte en material de análisis para proponer mejores estrategias educativas y de comunicación. El reto, con miras a la generación de valor hacia el cambio y el desarrollo, está en saber interpretar las realidades y elegir los medios adecuados para el fin comunicativo.

Palabras clave: contexto, cultura, territorio, institución educativa, convivencia, Félix y Susana, familias, niños, docentes. 


\section{Contenido}

Pág.

Resumen

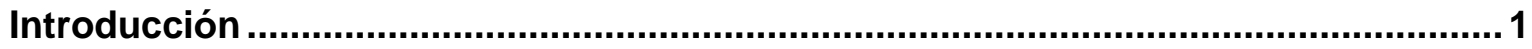

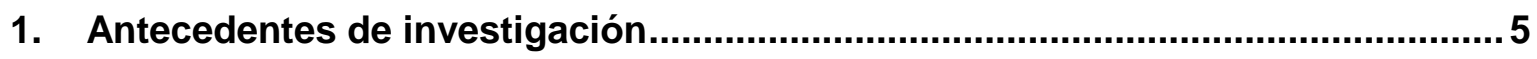

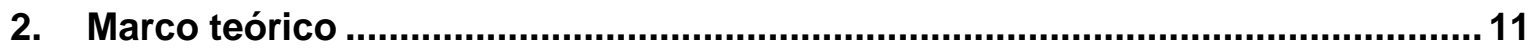

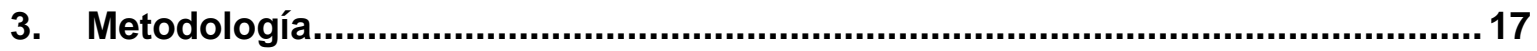

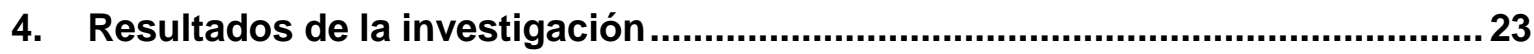

4.1 Aproximaciones al contexto escolar de la Institución Educativa Técnica

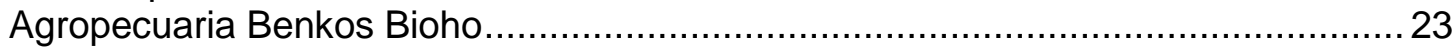

4.2 Aproximaciones al contexto escolar de la Institución Educativa Camino de Paz

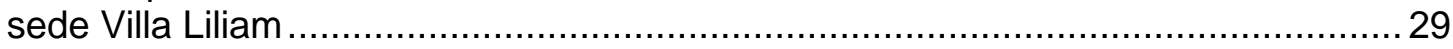

4.3 El significado de La Escuela ................................................................. 36

4.4 Los niños, las familias, los docentes y la escuela ..........................................39

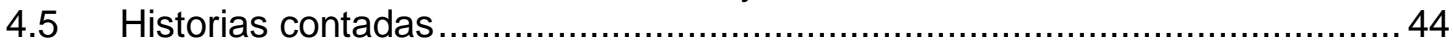

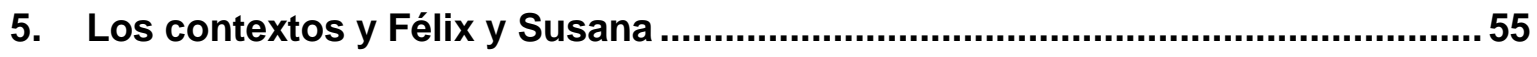

6. Conclusiones y recomendaciones ...................................................................59

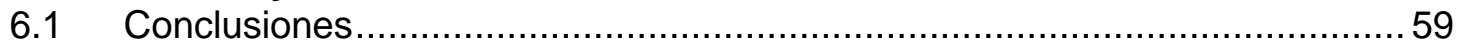

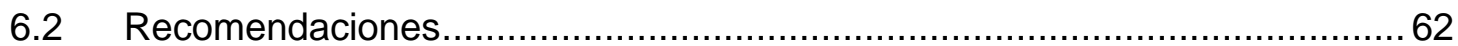

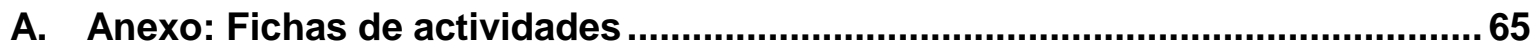

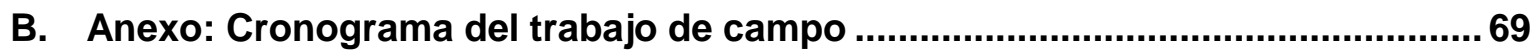

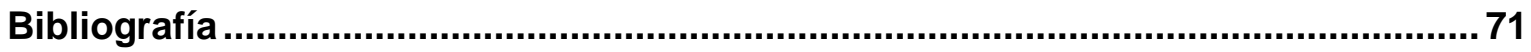




\section{Introducción}

Leer la realidad en la que nacen, crecen y viven las personas, identificar las dinámicas de sus contextos, darles valor, interpretarlos y, en algunos casos, reinterpretarlos, son un insumo importante para la construcción de la base bajo la que deben actuar las iniciativas de desarrollo social. Esta propuesta de investigación es un acercamiento a la construcción de esa base para el Programa de Educación para la Sana Convivencia Félix y Susana de la Fundación SURA.

Félix y Susana tuvo sus inicios en 2010 con la producción de un material pedagógico y una prueba piloto en 41 instituciones educativas del país. El Programa contribuye al fortalecimiento de las relaciones entre los niños, la familia y la escuela mediante el desarrollo de capacidades en los educadores como facilitadores del proceso de formación, a partir del uso didáctico de materiales educativos, la formación y el acompañamiento a docentes, el trabajo con las familias y la socialización de experiencias de aula. Tiene como punto de partida el reconocimiento del cuerpo, las emociones, la diversidad; promueve además la construcción de ambientes protectores.

Actualmente Félix y Susana se implementa en la básica primaria de 221 instituciones educativas rurales y urbanas de los departamentos de Antioquia, Atlántico, Bolívar, Cundinamarca, San Andrés, Norte de Santander, Valle del Cauca, Cauca y Risaralda; bajo una misma línea de operación, sin diferenciar el tipo de institución en la que se encuentra -rural o urbana- del interior del país o de la zona costera. La implementación incluye, entre otras: entrega de material educativo conformado por 10 juegos que abordan cada uno un tema específico, formación a docentes y directivos, y acompañamiento presencial durante tres años a cargo de profesionales de disciplinas de las áreas sociales y humanas. Cada profesional aporta desde su propia intuición, conocimiento y visión, elementos 
diferenciadores en el acompañamiento; sin embargo, no existe documentación ni lineamientos específicos que sustenten dichas actuaciones diferenciadoras.

Considerando que las características culturales de cada región son tan diversas y que influyen en la construcción de los contextos escolares y por ende en los procesos educativos de las instituciones, esta investigación realiza una comparación de dos instituciones educativas ubicadas en dos territorios en los que parecieran obvias las diferencias culturales: la institución Educativa Camino de Paz Sede Villa Liliam ubicada en la ciudad de Medellín, Antioquia, y la Institución Educativa Técnica Agropecuaria Benkos Bioho de San Basilio de Palenque ubicada en el corregimiento San Basilio de Palenque en el municipio de Mahates, en el departamento de Bolívar.

La investigación es un espacio de análisis cultural para comprender la diferencia del otro y así poder generar mejores estrategias formativas; y a su vez, propuestas comunicativas efectivas y pertinentes. El reto de la comunicación con miras a la generación de valor hacia el cambio y el desarrollo, está en saber interpretar las realidades y elegir los medios adecuados para el fin comunicativo. Aportar al desarrollo de una mejor sociedad parte de entender cómo es el comportamiento de los seres humanos desde los primeros años de vida. La investigación se desarrolló con un enfoque epistemológico hermenéuticointerpretativo, bajo la metodología etnográfica de observación participante.

\section{Pregunta de investigación}

- ¿Cómo influye el contexto cultural en la implementación de programas específicos como el de Félix y Susana en el ámbito escolar?

\section{Preguntas de investigación específicas}

- ¿Cuáles son las características culturales principales que influyen directamente en la construcción y comunicación de estos Programas?

- ¿Son las diferencias culturales y territoriales entre Medellín y San Basilio de Palenque tan marcadas como para adaptar el programa educativo Félix y Susana según la región donde se implemente? 


\section{Objetivo general}

- Analizar las características culturales que influyen en los contextos escolares de básica primaria de dos instituciones educativas, una en Medellín y la otra en San Basilio de Palenque, para el caso específico de Félix y Susana.

\section{Objetivos específicos}

- Identificar las características culturales principales que influyen directamente en la construcción y comunicación del Programa Félix y Susana.

- Comparar los contextos escolares de Medellín y San Basilio de Palenque.

- Documentar historias y experiencias que evidencien cómo la cultura y la conformación del territorio inciden directamente en el desarrollo del Programa Félix y Susana.

\section{Sobre el Programa Félix y Susana de la Fundación SURA}

Félix y Susana es un programa de educación para la sana convivencia dirigido a la básica primaria, que contribuye al fortalecimiento de las relaciones entre los niños, la familia y la escuela mediante el desarrollo de capacidades en los educadores como facilitadores del proceso de formación.

El Programa resuelve, entre otras, dos problemáticas: la ausencia de formación en temas asociados a la sana convivencia a partir de las funciones biológicas, sicológicas y sociales del ser humano desde los primeros años, y el desconocimiento de los signos y síntomas asociados al abuso y maltrato infantil dentro y fuera del aula, así como su impacto en el desarrollo cognitivo y social. Tiene como prioridad el reconocimiento del cuerpo, las emociones, la diversidad; concibe la sexualidad de manera integral, considerando lo psicológico y lo sociocultural, más allá de lo biológico, entendiendo que la sexualidad está presente a lo largo de toda la vida del ser y que es determinante en la manera como nos relacionamos con nosotros mismos y con los demás. 
Félix y Susana tiene como punto de partida la lúdica, a través de un material educativo conformado por 10 juegos, que facilita la apropiación y divulgación de conocimientos y la generación de conversaciones entre docentes, estudiantes y familias, que dejen entrever las realidades en las que crecen los niños y niñas, como situaciones de maltrato y abuso. Contribuye a que los niños desarrollen una relación saludable con su cuerpo y establezcan relaciones de respeto y cuidado, ubica al aula como un entorno protector en el que además del proceso educativo se identifiquen, prevengan y generen procesos de resiliencia. Para Félix y Susana la escuela es el punto de encuentro, el espacio donde confluyen los actores y en el que se desarrolla el proceso educativo.

La comunicación tiene un papel muy importante en el desarrollo del Programa, está presente en los materiales educativos con los que se busca generar conversaciones; en la divulgación del Programa que es clave para gestionar alianzas y convenios interinstitucionales; y en su sostenibilidad en las instituciones educativas, puesto que luego de los tres primeros años de acompañamiento presencial por parte del equipo del Programa, el acompañamiento a las instituciones debe hacerse a través de medios no presenciales y formatos de comunicación alternativos que lleven conocimiento a docentes, familias y niños.

\section{Temas que aborda el Programa:}

- El cuerpo, por dentro y por fuera

- Las relaciones, consigo mismos, con otros, con el entorno

- La diversidad

- Las responsabilidades y derechos de niños y niñas

- Las emociones

- Los sentidos

- El proyecto de vida

\section{Algunas cifras:}

- Presencia en 9 departamentos de Colombia, en República Dominicana y El Salvador

- 221 instituciones educativas implementan el Programa

- 2.800 educadores participan del Programa

- Más de 80 mil niños aprenden con Félix y Susana 


\section{Antecedentes de investigación}

La implementación del Programa Félix y Susana inició a partir del interés de la Fundación SURA de llevar a instituciones educativas un material pedagógico que abordara el cuerpo humano y la relación de cada ser con otros y su entorno. Dicha iniciativa contó con el apoyo de EPS SURA e IPS SURA. De este primer interés surge el diseño del material, la metodología general de implementación del Programa y el pilotaje del material en instituciones educativas.

En el año 2009, la Corporación Gilania se sumó a esta iniciativa para evaluar y cualificar el material didáctico de Félix y Susana en escenarios educativos, es decir, en sesiones pedagógicas que involucraran procesos de enseñanza - aprendizajes. Este fue el primer paso para fortalecer el Programa y las dinámicas pedagógicas necesarias para la futura utilización del material. La investigación, de corte cualitativo, en la que se analizó el material y su relación con los sujetos, realizó un inventario crítico y un pilotaje del material en cuatro instituciones educativas en Medellín y Marinilla con el ánimo de analizar cada juego de Félix y Susana a través de métodos de análisis, interpretación y síntesis, mediante la técnica de observación.

La investigación basó su análisis en la aplicabilidad del material según la edad de los menores (básica primaria) y su adaptabilidad a contextos rurales y urbanos; sobre esto último, cabe resaltar que en la salida a terreno se encontró con que los límites de las instituciones educativas elegidas eran difusos, predominando ambientes semirurales y semiurbanos; finalmente se realizó el trabajo de campo en Medellín y Marinilla, en una institución urbana, una rural, una semiurbana y la otra semirural.

Sobre dicha investigación se presentó un documento para uso interno de la Fundación SURA en el que se especifican recomendaciones sobre el diseño del material y la metodología propuesta para su uso en las aulas de clase.

Durante el año 2009 y 2010 la Corporación Gilania realizó, además, un proceso de fundamentación teórica del Programa consignado en una serie de documentos internos. 
Esta misma entidad -Corporación Gilania-, en el año 2011, desarrolló una investigación en 82 instituciones educativas de Antioquia, Barranquilla y Bogotá, sobre el acompañamiento virtual necesario a las instituciones educativas que participan del Programa. En este mismo año, la Corporación realizó un estudio sobre los efectos positivos o logros producidos por el material en las instituciones educativas en las que se venía implementando el Programa desde hacía un año.

Adicionalmente, el equipo del Programa viene haciendo una caracterización de cada institución en la que Félix y Susana está presente, el documento muestra una información muy general con datos inconclusos que no fueron tenidos en cuenta por no estar actualizados en el momento en el que se desarrolló esta investigación. Allí se especifican aspectos relacionados con el Proyecto Educativo Institucional -PEI-, los comités de convivencia, información básica sobre las familias, datos de deserción escolar, proyectos transversales de la institución, entre otros.

Referencio, además, dos tesis en las que en un comienzo encontré elementos similares con esta propuesta de investigación, desde el punto de vista de la educación enmarcada en un territorio, pero que fui descartando a medida que profundizaba en cada una de ellas. La primera, Percepciones de los sujetos en situación de vulnerabilidad sobre el territorio y la relación con el derecho a la educación, en la vereda Granizal (Bello - Antioquia), de Andrés Felipe Ríos Pineda; fue realizada en el año 2014 y aborda la educación como un derecho fundamental, aclarando que no necesariamente depende del Estado su implementación, puesto que habría que empezar por analizar la percepción social sobre lo que significa la educación en un territorio específico.

El otro trabajo de investigación titulado El estudio del territorio a través de un semillero de investigación en educación para las ciudadanías, de Juan David Acevedo, presentado en el año 2014, propuso encontrar diferentes estrategias de enseñanza - aprendizaje de las ciencias sociales, en especial lo concerniente a geografía y ciudadanía, a través de un semillero de investigación con estudiantes de décimo grado del Colegio La Salle de Bello en Antioquia.

Ambas investigaciones presentan una fuente bibliográfica importante y dos visiones para profundizar en el concepto territorio y en la apuesta por la educación. 
Además, el libro Diversidad cultural en la formación de maestros, sistematiza las experiencias de cuatro escuelas normales superiores catalogadas como étnicas, compiladas por Alberto Gómez Martínez y Wilson Armando Acosta Jiménez. De la publicación, referencio la metodología utilizada para la recopilación de la información, ya que la propuesta estuvo dirigida al trabajo directo con los educadores a través de unas sesiones que motivaron a los docentes a la elaboración de escritos. Así mismo, rescato la reflexión que hacen sobre lo etnoeducativo y el perfil del docente para dar cumplimiento a la necesidad de una educación pensada en la diversidad, puesto que aunque en las instituciones educativas seleccionadas para esta publicación, la mayoría de la población proviene de comunidades indígenas o afrocolombianas, en el mismo libro hacen la siguiente salvedad:

(...) no es sólo una propuesta para plantear en escuelas de pequeñas y aisladas poblaciones donde se concentran las comunidades indígenas o afrocolombianas, sino en todo el territorio nacional, en especial en las grandes ciudades, que tienen la población más multicultural y donde las estadísticas registran los más altos niveles de intolerancia de todas las índoles. (Gómez \& Acosta, 2006, p.20)

En la Revista Colombiana de Educación No. 69, el docente Edisson Díaz Sánchez publica un artículo titulado Reflexiones pedagógicas sobre la formación de docentes en los estudios escolares afrocolombianos, en el que enumera las diversas posibilidades de formación de los docentes en Colombia y hace especial énfasis en el quehacer de un docente con formación en etnoeducación. Lo traigo a colación por la población afrodescendiente en la que se enfoca esta investigación, no sólo aquella que está ubicada en San Basilio de Palenque, sino las personas desplazadas a la ciudad de Medellín y que pertenecen a comunidades afro. El artículo pone en evidencia el desconocimiento en el que, por años, estuvieron las comunidades indígenas y afrodescendientes del país, y se suma al llamado que hacen muchos autores como Boaventura De Sousa Santos en “(...) visibilizar los conocimientos, los saberes, las prácticas y las tradiciones de los pueblos primitivos y ancestrales que históricamente han habitado los territorios que proverbialmente han estado bajo el dominio del capitalismo global y el colonialismo", (Díaz, 2015, p.189). En ese orden de ideas, el autor del artículo plantea la necesidad que los docentes estén en la capacidad de enseñar de acuerdo a los conocimientos de las comunidades en las que se ubican y dar a conocer los saberes ancestrales. 
Los talleres utilizados para recopilar información y un análisis comparativo, son los dos aspectos que referencio de la investigación Justificaciones morales de dos grupos de niños y niñas acerca de la sexualidad, desarrollada entre agosto de 2004 y julio de 2009 por Carlos Bolívar Bonilla, docente del Programa de Psicología de la Universidad Surcolombiana de Neiva, de la que publica el artículo Justificaciones morales de los niños y niñas acerca de la sexualidad en la Revista Latinoamericana de Ciencias Sociales, Niñez y Juventud de la Universidad de Manizales y el Centro Internacional de Educación y Desarrollo-CINDE-. En el artículo, el docente expone la metodología utilizada, basada en la aplicación de 5 actividades con los niños y un análisis comparativo por género y por entidad educativa pública y privada, además de las conclusiones de la investigación en la que cobra valor el significado de sexualidad, y cómo la asumen los niños de este territorio (Neiva).

En el artículo El entorno social como factor determinante de la convivencia escolar publicado en la revista Gestión y Región No.18, se exponen los resultados de la investigación Factores de violencia urbana que afectan la convivencia escolar en algunos estudiantes de quinto grado de la Institución Educativa Villa Santana del Municipio de Pereira, Risaralda, de las docentes Ángela Patricia Sánchez Rodríguez y Maricela Restrepo Marín. En la investigación de tipo etnográfico de observación participante, se realizaron entrevistas a grupos focales de estudiantes de quinto de primaria y una entrevista semiestructurada a la Coordinadora de Convivencia Escolar de la Institución, además se consideró el diario de campo de las investigadoras. Dentro de los aspectos a destacar se tiene en cuenta la comunidad considerada como vulnerable en la que los niños viven en ambientes conflictivos y llevan los comportamientos agresivos de sus entornos al aula de clase. La investigación hace un llamado al acompañamiento de la familia y a la falta de proyecto de vida de los niños y niñas.

En el artículo Comunicación verbal y no verbal en una institución educativa distrital y su relación con los procesos de convivencia escolar, Olga Lucía Romero Rodríguez, Martha Patricia Vaca Vaca, María Jakelinn Galindo Parra y Santiago Sierra Alonso presentaron su investigación de tipo etnográfico de la que referencio el valor que se le da a la comunicación dentro del proceso de relacionamiento de los seres humanos, la conducta como unidad de comunicación en el que incluso el silencio es un mensaje que se emite y la relación entre lo que se dice y se hace, "(...) se hace necesario fortalecer los procesos de comunicación 
en la escuela, lo que sin duda promoverá la sana convivencia”, (Romero, Vaca, Galindo \& Sierra, 2016, p.90). La investigación se realizó con un grupo de 30 estudiantes entre los 8 y 11 años de edad y se utilizaron como herramientas de recolección de información la entrevista semiestructurada y la observación participante; se realizó un registro de video del material, que fue analizado teniendo en cuenta la comunicación verbal y la no verbal.

Que los niños aprendan a través de la lúdica es uno de los principios de Félix y Susana. Respecto a la lúdica como herramienta pedagógica, los docentes Patricia Posso Restrepo, Miriam Sepúlveda Gutiérrez, Nemesio Navarro Caro y Carlos Egidio Laguna Moreno realizaron una investigación titulada La lúdica como estrategia pedagógica para fortalecer la convivencia pacífica entre estudiantes del grado tercero del Colegio Brasilia Bosa, jornada tarde, sobre la que publican un artículo en la Revista Lúdica pedagógica No. 21 del año 2015. De este texto resalto:

(...) se concluye que el juego, además de tener un gran valor educativo para el niño desde el punto de vista pedagógico, constituye una actividad vital espontánea y permanente del niño, a partir del cual crea y fomenta normas de relaciones sociales, culturales y morales, convirtiéndose por demás en un agente de transmisión de ideas. (Posso, Sepúlveda, Navarro \& Laguna, 2015, p.173)

Además que: "Por medio de actividades lúdicas, se ha logrado potenciar la expresión emocional positiva de los niños para que aprendan a expresar sus sentimientos, particularmente el enojo y la frustración, de maneras que no son agresivas o destructivas y aprenden autocontrol" (Posso et al., 2015, p.174). 


\section{Marco teórico}

Estamos ubicados en un territorio, pertenecemos a alguno porque existen "juegos de poder" que delimitan los espacios geográficos, creando barreras entre una zona y otra. Pero más allá de esas fronteras impuestas, existen características territoriales que surgen de procesos históricos, culturales, sociales, económicos y demográficos que crean diferencias entre uno y otro sector. En la apuesta de analizar comparativamente dos territorios diferentes, se hace necesario adoptar un concepto de territorio que va más allá de aquel propuesto por las ciencias naturales, la geografía, la economía y las ciencias políticas; un concepto en el que el territorio se enmarca en la identidad construida a partir de unos límites geográficos:

El territorio surge, por lo tanto, como resultado de una acción social que, de forma concreta y abstracta, se apropia de un espacio (tanto física como simbólicamente). De ahí la denominación de un proceso de construcción social. En un sentido antropológico, territorio es un ambiente de vida, de acción, y de pensamiento de una comunidad, asociado a procesos de construcción de identidad. (Flores, 2007, p.36)

Este espacio, físico y simbólico, adquiere relevancia al funcionar como un sustrato significativo de cultura y, por ende, marco de referencia en la construcción de la identidad social, en el que no sólo se transforman las personas que lo habitan, su interacción social, su haber histórico y cultural, sino también el mismo territorio (Gutiérrez, 2009, P.120).

La cartografía, el clima, y la historia, son en parte factores que influyen en la construcción de un territorio y su cultura, y ésta a su vez, incide en la estructuración de los contextos escolares. En la literatura encontramos documentos en los que se evidencia un cambio en el concepto de educación teniendo en cuenta la temporalidad, es decir, es común hallar referencias de cómo era la educación hace treinta años por ejemplo y cómo es o debe ser ahora. Lo cierto es que tanto el tiempo como el territorio influyen directamente en la manera como evolucionan las escuelas. En La educación como práctica de la libertad de Paulo Freire (2011), encontramos un ejemplo de cómo debería asumirse una educación con miras a la democratización del conocimiento, en este caso contextualizándola en el 
territorio brasilero, es decir, aunque el concepto de educación puede transferirse a otros espacios, son importantes las características territoriales en el que se desarrolla:

Una educación que lleve al hombre a una nueva posición frente a los problemas de su tiempo y de su espacio. Una posición de intimidad con ellos, de estudio y no de mera, peligrosa y molesta repetición de fragmentos, afirmaciones desconectadas de sus mismas condiciones de vida. (Freire, 2011, p.87)

En este texto Freire propone una educación que lea el contexto, que se adapte a él, una educación abierta al cambio, y en la que el diálogo cumple un papel relevante.

Educación que lo coloque en diálogo constante con el otro, que lo predisponga a constantes revisiones, a análisis críticos de sus 'descubrimientos', a una cierta rebeldía, en el sentido más humano de la expresión; que lo identifique, en fin, con métodos y procesos científicos. (Freire, 2011, p.84)

En ocasiones la escuela ha sido considerada como un espacio de tránsito para niños, adolescentes y jóvenes, en el que se transmiten conocimientos, valores, hábitos y normas (Longás, Civís, Riera, Fontanet, Longás y Andrés, 2008), pero ésta indudablemente va más allá. Es cierto que es un espacio, una infraestructura que con sólo nombrarla trae consigo un sinnúmero de representaciones visuales, auditivas y psicológicas. Nombrar "La escuela", tiene una influencia directa en los recuerdos de quien alguna vez la ha pisado. Su nombre y su espacio físico son así mismo referente de un pueblo, determinada escuela da o quita estatus, dice mucho o dice poco. Sin embargo, más allá de la construcción de lo que puede generar la escuela y su espacio físico, es indudable que sí es un lugar en el que habita la heterogeneidad del ser, en el que se forma, se construye y se crean las bases humanas. Pero también es cierto que en la escuela no hay sólo niños, adolescentes y jóvenes, en ella se relacionan docentes, directivos, familiares, vecinos, todos ellos con sus creencias y costumbres, sus historias y sus culturas; todo fluyendo en un sólo espacio.

Otros autores manifiestan igualmente un cambio en la educación, en la que deja de verse como un patrimonio de la escuela y pasa a ser una característica humana, que trasciende la etapa escolar y se proyecta a la comunidad. De esta manera se asume que hay una corresponsabilidad en los procesos educativos, en los que el educador no es el único responsable de dicho proceso. 
Si la educación no es compartida por los distintos agentes socioeducativos, no aborda y se nutre de la dimensión comunitaria y no genera desarrollo, cambio y transformación en las sociedades, no puede ser concebida como educación. En este sentido, una educación que no se limita a la escuela, que sale de las paredes de las aulas para comprometer a la sociedad en su conjunto y que confía en el entorno local deviene un asunto de la comunidad. (Longás et al., 2008, p.140)

Sin embargo, sigue existiendo el riesgo de caer o permanecer en una educación colonizadora o colonialidad del saber, haciendo referencia al concepto que utilizan algunos autores como Boaventura de Sousa y Catherine Walsh, sobre el poder que tienen las grandes potencias de determinar qué es conocimiento y cómo debe funcionar la educación (Walsh, 2007). Adaptando el término a lo que concierne a esta investigación, se podría hacer una comparación con el poder de la empresa privada que sugiere el modo de educación que se debe implementar en las escuelas de básica primaria respecto a temas de convivencia, relacionamiento, sexualidad, caso específico el Programa Félix y Susana. Por ello, es necesario tener presente que somos una sociedad con culturas diferentes; es obligatorio mirar al otro, su espacio de interrelación, su identidad, recuperar los conocimientos presentes en la memoria de los sabios y ancianos, en la naturaleza y la cotidianidad.

Y aquí tiene cabida el concepto de educación para la diversidad:

Educación, en y para la diversidad, significa, además de promover el fortalecimiento de la identidad étnica y cultural, trabajar en la perspectiva de que cada persona, cada grupo se abra a los demás y en esa interrelación se descubra a sí mismo. (Aristizábal, 2000, p.67)

No se debe caer en el mal uso del concepto cultura, en el que éste se asocia a folklore, tradición, costumbre y que lleva a pensar que sólo hay diversidad cultural, donde hay diversidad étnica (Cortez, 2015, p.26). Por otro lado, es importante precisar como referente de esta investigación enmarcada en un programa de estudio en comunicación, desarrollo y cambio social, la relación de la cultura con la comunicación:

Si la cultura es eminentemente comunicativa, podemos asegurar que no es una cualidad de sujetos aislados sino de sujetos sociales. La cultura es una elaboración colectiva que va transformándose a causa de la interacción entre sujetos y grupos 
diversos. La cultura entonces puede ser vista en sentido general como la capacidad de todos los humanos de generar sistemas simbólicos, y en un sentido específico como cada una de las diferentes formas en que los grupos humanos desarrollan dicha capacidad en tiempos y espacios concretos. (Cortez, 2015, p.33)

Si la cultura es algo de grupos y relaciones entre sujetos, la cultura deberá incidir y manifestarse en la manera como convivimos y la escuela es uno de esos primeros espacios donde se genera convivencia entre pares.

Si se hace el ejercicio de partir del reconocimiento del otro, para el tema de educación sexual es un reto poner a conversar las distintas visiones sobre la sexualidad que por años se han instaurado en la memoria cultural de las sociedades, donde para muchos lo sexual es un tema tabú, del que no se habla. Hoy en día, psicólogos y médicos dejan por sentada la posición que de sexualidad se debe hablar, como estrategia de prevención contra abusos y maltratos físicos, sexuales y emocionales. El sector educativo debe crear un entorno protector para niños y niñas, es decir, tener las competencias suficientes para proteger a los niños y niñas de cualquier situación de abuso que pueda presentarse en los entornos educativos, propiciar espacios que fomenten relaciones de confianza en los que se permita reportar situaciones anormales que los afecten y, en el caso de que las hubiere, saber cómo intervenir (Cuadros y Ordóñez, 2006, p.147). Pero como la misma Walsh lo dice: "El interés es, más bien, crear, construir y apuntar caminos decoloniales que no niegan la modernidad, pero que permiten vivirla de otra manera, sin ser absorbida y controlada por ella" (Walsh, 2007, p.32).

La escuela tiene también el rol de enseñar a sus educandos cómo cuidarse y cuidar a los demás, así como promover la salud y bienestar de la comunidad educativa, esto no a través de una cátedra de salud, sino por medio de sus programas transversales. Con la promoción de la salud se fomenta el respeto a las diferencias, la equidad de género, la diversidad de saberes y culturas, la participación, la toma de decisiones (Gumucio, 2010, p.71); en fin, se enseña a convivir.

Parafraseando a Moreno Abril, Robles afirma que: "Si el Sistema educativo trata realmente de preparar al alumno para la vida, debe formarlo también para que sea capaz de tomar, de una manera razonada, decisiones que van a tener consecuencias claras sobre su salud y la salud de la comunidad" (Robles, 1996, p.94). Y allí la comunicación tiene un papel 
relevante, como ejercicio educativo que genera cambios de conducta dirigidos a mejorar la salud (Beltrán, 2010, p.36) y a construir relaciones a favor del bienestar de la comunidad.

En su libro A la Educación por la Comunicación, Mario Kaplún divulga el caso del maestro francés Célestin Freinet, quien agotado del sistema educativo de los años 20: "Esa enseñanza memorística, mecánica, represiva, divorciada de la vida, que 'deja a los niños en una actitud pasiva y amorfa' solo engendra fracasos" (Kaplún, 2001, p.20), recurre a un medio de comunicación para dinamizar sus clases, la imprenta. Muy a lugar viene Félix y Susana a las aulas de clase, no como una imposición, sino como una herramienta que facilita la labor del docente y promueve la creatividad de educadores y educandos. Félix y Susana no es en sí un medio de comunicación como el que propone Freinet y demás casos que cita Kaplún en su libro, pero sí se convierte en el medio para "potenciar la palabra de los otros" (Kaplún, 2001, p.4), de los niños, de los maestros, de los padres. Porque como también lo dice este autor: "El participante que, quebrando esa dilatada cultura del mutismo que le ha sido impuesta, pasa a decir su palabra y construir su propio mensaje... en ese acto de comunicarlo a los otros se encuentra consigo mismo" (Kaplún, 2001, p.34). Félix y Susana promueve precisamente la comunicación entre maestros y alumnos y padres e hijos teniendo a la educación como eje transversal del proceso comunicativo. 


\section{Metodología}

Esta investigación tiene un enfoque epistemológico hermenéutico-interpretativo que consiste en leer e interpretar la realidad de la sociedad, sus comportamientos y costumbres para, en este caso, arrojar resultados que permitan entender la manera como se constituyen dos grupos poblacionales, y su efecto o no en la implementación de un programa educativo. "La cultura se hallaba construida como un conjunto de conductas características, de ceremonias y de gestos susceptibles de registro y explicación por parte de un observador entrenado" (Clifford, 2001, p.49). Se lleva a cabo bajo la metodología etnográfica de observación participante en la que se describe, y se hace un análisis crítico de la implementación del programa Félix y Susana de acuerdo con el contexto cultural de los grupos seleccionados: San Basilio de Palenque y el barrio Villa Liliam en Medellín. Según Guber, en las investigaciones de tipo etnográfico: "el investigador no se propone explicar una cultura sino interpretarla o comprenderla" (Guber, 2001, p.42).

En esta investigación el trabajo de observación es relevante, parte de una documentación y revisión bibliográfica, que permita la adquisición de conocimientos históricos básicos, antes de llegar al trabajo directo con las comunidades, donde cobra verdadero valor la observación y la escucha, de ésta dependerá el trabajo posterior de análisis, "Es cierto que la observación no es del todo neutral o externa pues incide en los sujetos observados; asimismo, la participación nunca es total excepto que el investigador adopte, como "campo", un referente de su propia cotidianeidad", (Guber, 2001, p.62).

Otro aspecto importante es el lenguaje: "Al comunicarse entre sí la gente informa sobre el contexto, y lo define al momento de reportarlo" (Guber, 2001, p.44) y con él, el relato, que según la teoría interpretativa que señala Watson y que cita Guber: "Los relatos no son espejos pasivos de un mundo exterior, sino interpretaciones activamente construidas sobre él" (Guber, 2001, p.43). Es así como en el trabajo de campo de esta investigación las actividades estuvieron dispuestas para que no sólo el investigador utilizara el lenguaje para acercarse a la población, sino para que también a partir del lenguaje y el relato, la comunidad expresara su realidad, ofreciéndole información valiosa al investigador.

Tanto la observación como la escritura cumplen un papel muy importante en este proceso de registro, descripción, interpretación y análisis; en la observación está la fuente de 
conocimiento; y la escritura es el vehículo que facilita la decantación de la información recopilada y la socialización de ideas concretas. Al respecto, valoro las palabras del periodista Juan José Hoyos:

(...) (la etnografía) es una forma de trabajo que permite la descripción y el análisis de un campo social específico, una escena cultural determinada: una localidad, un barrio, una fábrica, una familia, una práctica social, una institución. Tiene, pues, un componente de observación y descripción y un componente de reflexión sobre el material recopilado... coincide con el método investigativo del periodismo en que desde un comienzo el trabajo de campo tiene como meta final la escritura. El etnógrafo es, en lo esencial, un escritor. Escribe constantemente notas, diarios y fichas, y los resultados de su investigación los expresa en textos. Su representación de la realidad social está, pues, condicionada por la escritura. (Hoyos, 2003, p.102)

Para llegar a conocer esa localidad, ese barrio, es necesario interactuar en ese espacio con la comunidad, para que sea ella misma la que de cuenta de las realidades de su contexto. Para Orlando Fals Borda y otros precursores de los métodos de investigación participativos, el conocimiento científico que produce la academia debe estar nutrido por el saber popular, y más aún, si la búsqueda de este conocimiento va en vía del bienestar comunitario. Para el caso de esta investigación, este saber es una mezcla entre la academia, la empresa y la comunidad. No obstante, en esta investigación es más importante la observación que la participación, evitando tomar notas en terreno lo que podría distraer al investigador al interferir en su capacidad de observar y de desarrollar adecuadamente las actividades. Se llevó un diario de campo con el registro de notas una vez concluida la interacción con la comunidad, "Desde el ángulo de la observación, entonces, el investigador está siempre alerta pues, incluso aunque participe, lo hace con el fin de observar y registrar los distintos momentos y eventos de la vida social", (Guber, 2001, p.57).

El trabajo de campo se realizó en las instituciones educativas Camino de Paz sede Villa Liliam en Medellín y la Institución Educativa Técnica Agropecuaria Benkos Bioho de San Basilio de Palenque, donde se implementa el Programa. Se abordaron los dos públicos principales de Félix y Susana: Ios educadores, quienes lideran la implementación del Programa en las instituciones educativas y reciben formación y acompañamiento directo 
de Félix y Susana; y los estudiantes, quienes se convierten en el propósito final del Programa, disfrutan del material educativo y aprenden con Félix y Susana.

En esta investigación no se trabajó con las familias, porque el Programa no tiene estrategias de trabajo directo, constante y específico con cada familia, la incidencia en este primer entorno protector de los niños que es la familia, se presenta a través de la información y actividades que replican los educadores y los niños, y por medio de otros canales como la página web del Programa. A continuación se presenta el alcance del Programa en el Infográfico 3-1.

Infográfico 3-1: Impacto del Programa Félix y Susana

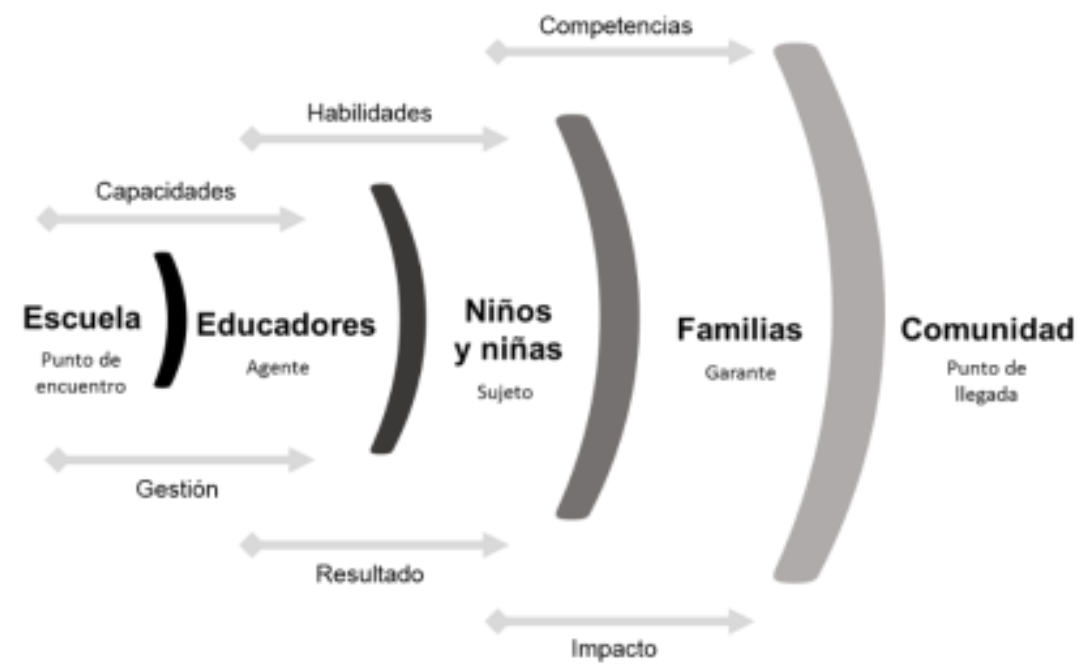

(Fuente: Fundación SURA, 2016)

La investigación se realizó por fases así:

\section{Fase I. Documentación.}

Revisión de material bibliográfico como libros, artículos e investigaciones; material publicado como videos, crónicas y reportajes que den cuenta de la realidad cultural de San Basilio de Palenque en Bolívar y el barrio Villa Liliam en Medellín.

\section{Fase II. Socialización del proyecto de investigación.}

Previo al trabajo de campo, se socializó el proyecto de investigación con los profesionales de Félix y Susana de estos territorios (personas que lideran la implementación del Programa en cada región) y con los rectores y coordinadores de las instituciones 
educativas, con miras a obtener el aval de los directivos para realizar los talleres de recopilación de información en las aulas de clase.

\section{Fase III. Trabajo de campo.}

El trabajo de campo se realizó en el segundo semestre de 2016 con la participación de 7 docentes y 13 niños en Medellín y 4 docentes y 11 niños en San Basilio de Palenque, en total 35 personas. Se incluyeron 3 tipos de herramientas para la recolección de datos, información y testimonios de docentes y niños:

- Actividad de creación de historias para niños y educadores. Esta herramienta se convierte en el punto de partida para escuchar a niños y docentes, es una excusa para generar conversaciones a partir de las historias que ellos puedan contar.

- Cartografía social. Permite identificar aquellos lugares cercanos a la institución educativa que influyen o pueden llegar a influir en el desarrollo de los niños, considerando que esos puntos de interacción comunitarios permean el comportamiento de los niños, entendiendo que lo que se enseña en la escuela debe guardar coherencia con lo que se enseña por fuera de ella.

- Entrevista semi_estructurada individual para docentes. A través de esta herramienta se indaga sobre la vida profesional y personal de los docentes, para conocer la percepción que tienen sobre sus estudiantes y la institución educativa, así como su experiencia con el Programa y los temas que éste aborda.

Inicialmente se tenía planteado realizar una encuesta a los niños, sin embargo y por sugerencia de una de las instituciones educativas, se replanteó esta actividad y se abordaron las preguntas de la encuesta en diálogo directo con los niños durante el desarrollo de las actividades mencionadas.

Todas las actividades estuvieron acompañadas del registro de lo observado en un diario de campo, fotografías, video y grabación de audio.

En el Anexo A de este informe, se adjunta la relación completa de las actividades realizadas en el trabajo de campo, en el Anexo B se agrega el cronograma de trabajo y el número de personas que participaron en la investigación por cada actividad. 


\section{Fase IV. Análisis de información.}

Una vez realizado el trabajo de campo se analizó la información considerando las siguientes variables:

- Los niños como sujetos de derechos

- Perspectivas de género

- El significado de la escuela

- El rol de las familias en la educación de los niños

- El rol de los educadores en la escuela

- La comunicación y relación entre padres, hijos e instituciones educativas; y entre estudiantes y educadores

Adicionalmente, se tuvo una mirada crítica frente al desarrollo de Félix y Susana en las instituciones educativas con el objetivo de proponer recomendaciones al Programa.

Fase V. Sistematización de la información y escritura del trabajo de grado. 


\section{Resultados de la investigación}

Una vez realizado el trabajo de campo en ambas instituciones educativas y el registro y sistematización de la información recopilada, se analizaron los datos, prestando especial atención a la clasificación de los testimonios que son la base del conocimiento que soporta la investigación.

Se pudo corroborar que el comportamiento de las personas está necesariamente ligado a las manifestaciones culturales de las que hacen parte y a los procesos históricos de los territorios en los que han vivido; que las formas de criar de las familias son un legado que se transmite de generación en generación, no siempre con consecuencias positivas para niños y niñas.

\subsection{Aproximaciones al contexto escolar de la Institución Educativa Técnica Agropecuaria Benkos Bioho}

Esta institución es la única localizada en el corregimiento de San Basilio de Palenque, tiene tres sedes y el Programa Félix y Susana opera en la sede de básica primaria. Para analizar el contexto de la institución es necesario observar las características de la población que están ligadas especialmente a la conservación y divulgación de la cultura palenquera, de la que se destaca:

Bailes típicos de la zona como mapalé, bullerengue, cumbia: los niños que participaron en la investigación (Anexo B) hicieron mención de esta actividad, dando a entender que aprender a bailar es parte natural de su proceso formativo y que cantar y tocar algún instrumento es una actividad recurrente en sus familias, "en el parador turístico hacemos presentaciones, bailes (...) mapalé, eso se lo enseñaron a uno" (J. E. Cañate, comunicación personal, 22 de noviembre de 2016). En conversaciones con la población y docentes se destaca igualmente la celebración de festividades en las que el baile, el licor y la fiesta son significativos, eventos que duran uno o varios días. "Mi papá tenía una banda de música, él era el que cantaba, pero él tuvo que crecer, por eso cantando no más, ya trabajando" (J. D. Cañate, comunicación personal, 22 de noviembre de 2016).

Peinados típicos y productos para la venta: aunque la innovación en los peinados se presenta tanto en hombres como en mujeres y cada peinado tiene un significado 
específico, cuenta una joven palenquera en el documental La Casa Pintada, Palenque de Colores (Uribe, 2014) que por ejemplo, "(el peinado) los hundiditos, el cual es muy representativo de acá de la comunidad, ya que estos representan la gastronomía palenquera, acá se pueden guardar semillas, monedas (...) nuestros pelos vienen siendo muy importantes en la época de la esclavitud cuando aquí nosotros plasmamos ideas", es importante resaltar el papel de la mujer palenquera en este oficio, quien en otra época lucía estos peinados para trazar rutas y esconder oro y semillas dentro del cabello. Las mujeres:

Divisaban el paisaje, los ríos, las montañas y las tropas del ejército español. Y en su pelo tejían lo que veían, a través de mapas de huida en marañas trenzadas, delimitando los senderos transitados (...) En sus cabellos enredados, las esclavas escondían pepitas de oro que lograban escarbar en su trabajo en la minería durante la Colonia. (Mojica, 2011)

Así mismo, la venta de productos fabricados con insumos de la zona está a cargo de las mujeres, en ese sentido, continúa siendo la mujer quien lleva y administra el dinero en el hogar:

La prodigiosa actividad que realizan las mujeres las libera del sometimiento total al marido, pudiéndose decir que la estabilidad de la familia depende más que todo de ellas.

La mujer ejerce un efectivo control sobre las finanzas familiares. El único aporte del hombre consiste en hacer la roza y traer a casa la cosecha, pero la venta de ésta se halla a cargo de las mujeres, quienes velan porque no falte el pan de cada día.

La actividad comercial es ejercida en su totalidad por el sexo femenino; recorren diariamente considerables distancias en busca de los mejores precios para los productos agrícolas. (Escalante, 1979, p.58)

Treinta y ocho años después de ser publicado el libro de Escalante, las mujeres son quienes continúan liderando la venta de productos palenqueros por fuera del municipio. Según cuentan los docentes que participaron en la investigación (Anexo B), algunas de las madres de sus estudiantes se desplazan a Cartagena, Barranquilla y zonas costeras para 
vender sus productos. "La cultura en palenque abla [sic] de... los dulce alegria [sic] coca enyucado queque [sic] dulce de coroso", (Y. V. Torre \& Y. M. Cañate, actividad de creación de historias en San Basilio de Palenque, 22 de noviembre de 2016). Estos productos, además de los peinados, la lengua y la música, han contribuido a la construcción de identidad de un pueblo, que además es reconocido por la Organización de las Naciones Unidas para la Educación, la Ciencia y la Cultura -UNESCO- (inscrito en 2008, originalmente proclamado en 2005) como Patrimonio Cultural Inmaterial de la Humanidad, así pues a través de las cocadas, la vestimenta y la particular forma de exhibir los productos en la cabeza, las mujeres palenqueras no sólo velan por las finanzas del hogar, sino que son además símbolo y representación de una cultura.

Una lengua propia de origen africano: indudablemente la lengua es una de las características que hace únicos a los palenqueros, ésta es transmitida de generación en generación por la familia y se constituyó en fuente de discriminación de los palenqueros en sus primeros intentos de conseguir trabajo por fuera de la comunidad, es la "(...) única lengua criolla de las Américas que combina una base léxica española con las características gramaticales de lenguas bantúes" (UNESCO, 2008).

En su libro Lengua y sociedad en el palenque de San Basilio, Nina S. Friedemann y Carlos Patiño (1983) relatan que en 1924 era poco el contacto de Palenque con el exterior. Comenzó la emigración de palenqueros cuando los ingenios de azúcar y la zona bananera empezaron a requerir brazos fuertes y se empezaron a presentar los primeros síntomas de discriminación cuando los escucharon hablar. Agregan:

Los primeros palenques fueron de negros bozales, es decir, de africanos recién desembarcados. Pero a finales del siglo XVII ya estaban conformados por criollos, negros experimentados en el Nuevo Mundo por hallarse en él desde largo tiempo, o bien por haber nacido en las colonias y así haber adquirido no sólo habilidades en el habla, sino la cortesía colonial surgida de la interacción amo blanco - esclavo negro, y otras destrezas. (Friedemann \& Patiño, 1983, p.45-46)

Ahora la conservación de su lengua los hace especiales, hoy en día es un orgullo hablar palenquero, así lo manifiesta Darlis, docente de la Institución Benkos Bioho: 
Estamos en las faldas de los Montes de María, y se conserva la lengua y las costumbres, algunas se han ido debilitando y todavía se mantiene esas ganas de seguirlas rescatando. Aquí en un tiempo los papás no querían que los hijos siguieran hablando la lengua palenquera porque cuando salían de aquí, de San Basilio de Palenque, por fuera se burlaban. Los papás y las mamás para que no se burlaran de sus hijos les quitaban la lengua cuando salían de Malagana en adelante, que no hablaran la lengua. Ahora no, para ellos es un orgullo hablar su lengua, mantener sus peinados, sus vestimentas, es algo que caracteriza a San Basilio. (D. Ramos, comunicación personal, 22 de noviembre de 2016)

Otro aspecto a tener en cuenta es la infraestructura del corregimiento, que continúa con ciertas limitaciones por el deterioro de su carretera principal. Sobresale en el pueblo una edificación de dos pisos construida para instalar la primera estación de policía de Palenque, y otras cuantas casas que donó la Gobernación de Bolívar que poco tienen que ver con la construcción tradicional; se conservan las casas bajas, las calles destapadas, la plaza principal y algunas edificaciones en construcción tradicional en bahareque con su cocina en el solar, cerca de madera y techos de paja. En la cocina de una casa pasa el tiempo el líder del grupo musical más famoso del municipio: Sexteto Tabalá, allí en el solar, recibe a los turistas para tocarles una canción, escuchar sobre sus giras de antaño y vender alguno de sus cd's.

Y aunque la Gobernación de Bolívar en alianza con entidades privadas ha implementado planes de desarrollo en Palenque, en los que se han visto resultados tangibles como la construcción de viviendas, pobladores cuentan, entre otras, que desde hace un tiempo el acueducto se dañó y no lo han arreglado. No hay alumbrado público, por lo que las calles permanecen a oscuras durante las noches.

A continuación se presentan fotografías: en la Imagen 4-1, una vivienda tradicional construida en bahareque; en la Imagen 4-2, una calle del poblado; en la Imagen 4-3, la entrada de la Institución Educativa Técnica Agropecuaria Benkos Bioho; en la Imagen 4-4, la cartografía social realizada por los niños, al respecto cabe resaltar que para los niños fue importante plasmar los límites del pueblo, explicar la ubicación espacial "Palenque es un pueblo que está formado en los Montes de María a 50 kilómetros de Cartagena" (J. E. Cañate, comunicación personal, 22 de noviembre de 2016), destacaron además los sitios donde ellos pueden disfrutar del tiempo libre como la plaza principal y la Casa de la Cultura. 
Los niños no mencionaron en particular dos lugares que los lugareños presentan al turista como sitios importantes para el municipio: un arroyo que pasa muy cerca del pueblo y un espacio deportivo donde se fomenta el boxeo en homenaje al campeón Kid Pambelé nacido en esas tierras.

Imagen 4-1: Casa en construcción tradicional en bahareque

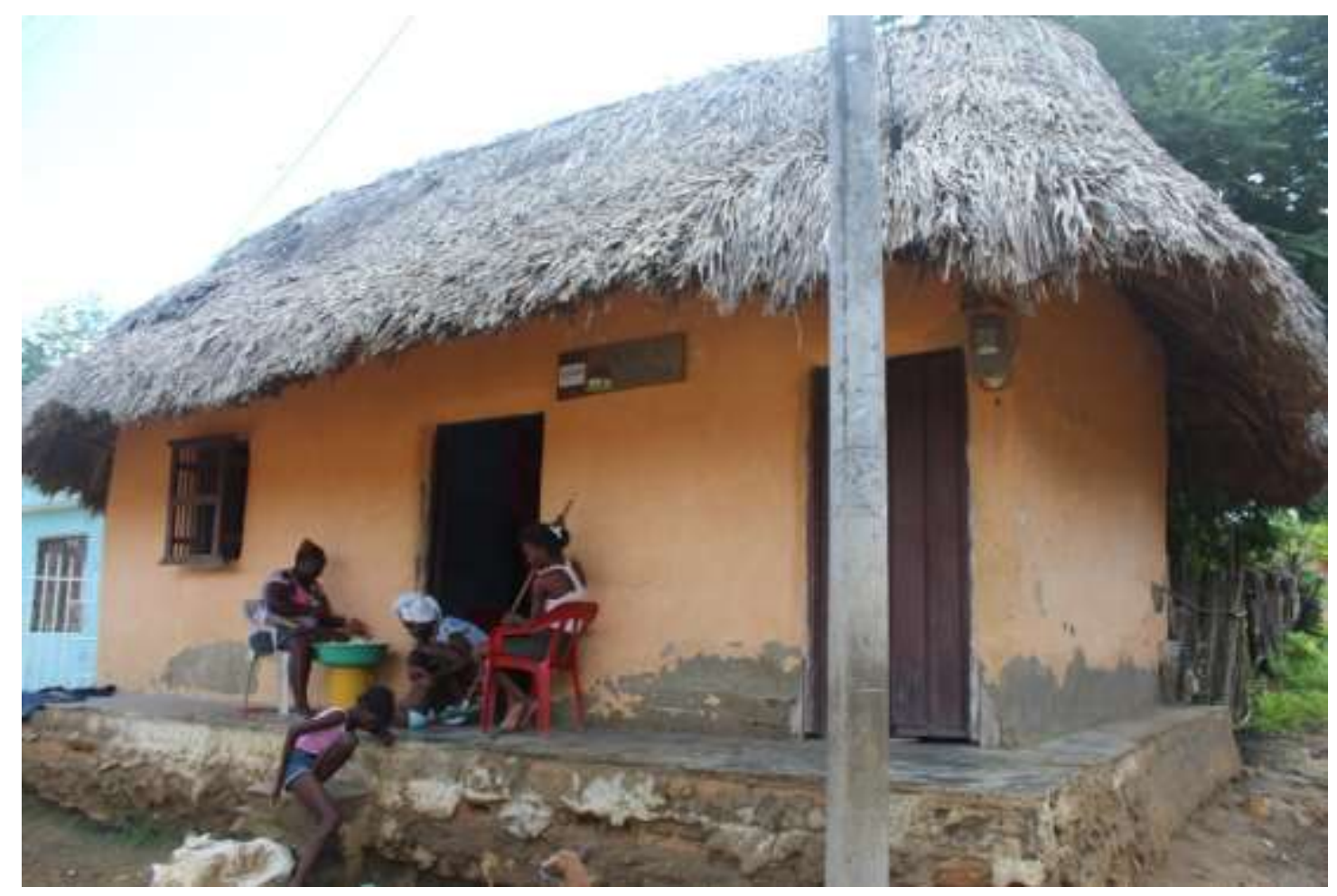

(Foto tomada por: Julia Correa, San Basilio de Palenque, 22 de noviembre de 2016) 
Imagen 4-2: Una calle de Palenque

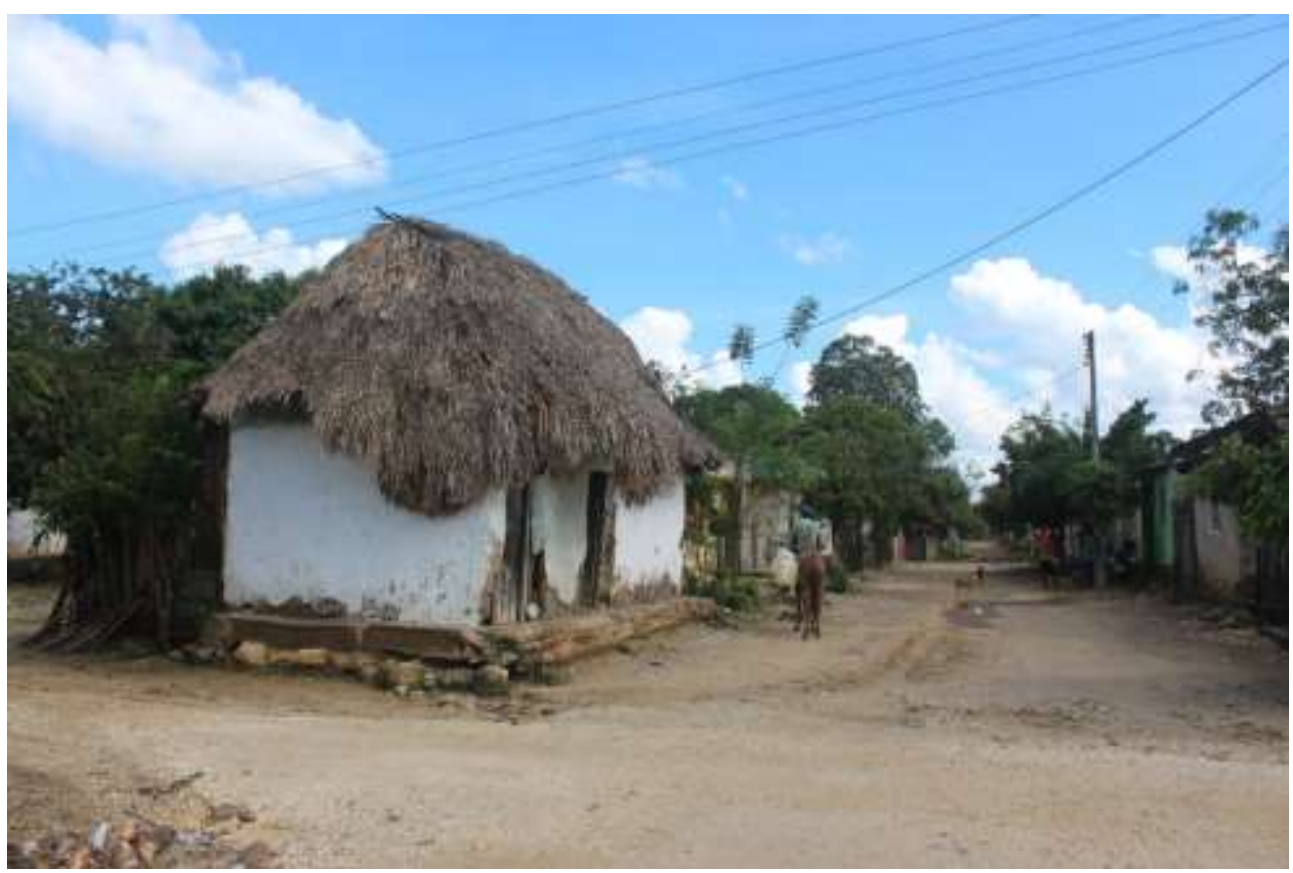

(Foto tomada por: Julia Correa, San Basilio de Palenque, 22 de noviembre de 2016)

Imagen 4-3: Fachada de la Institución Educativa Técnica Agropecuaria Benkos Bioho

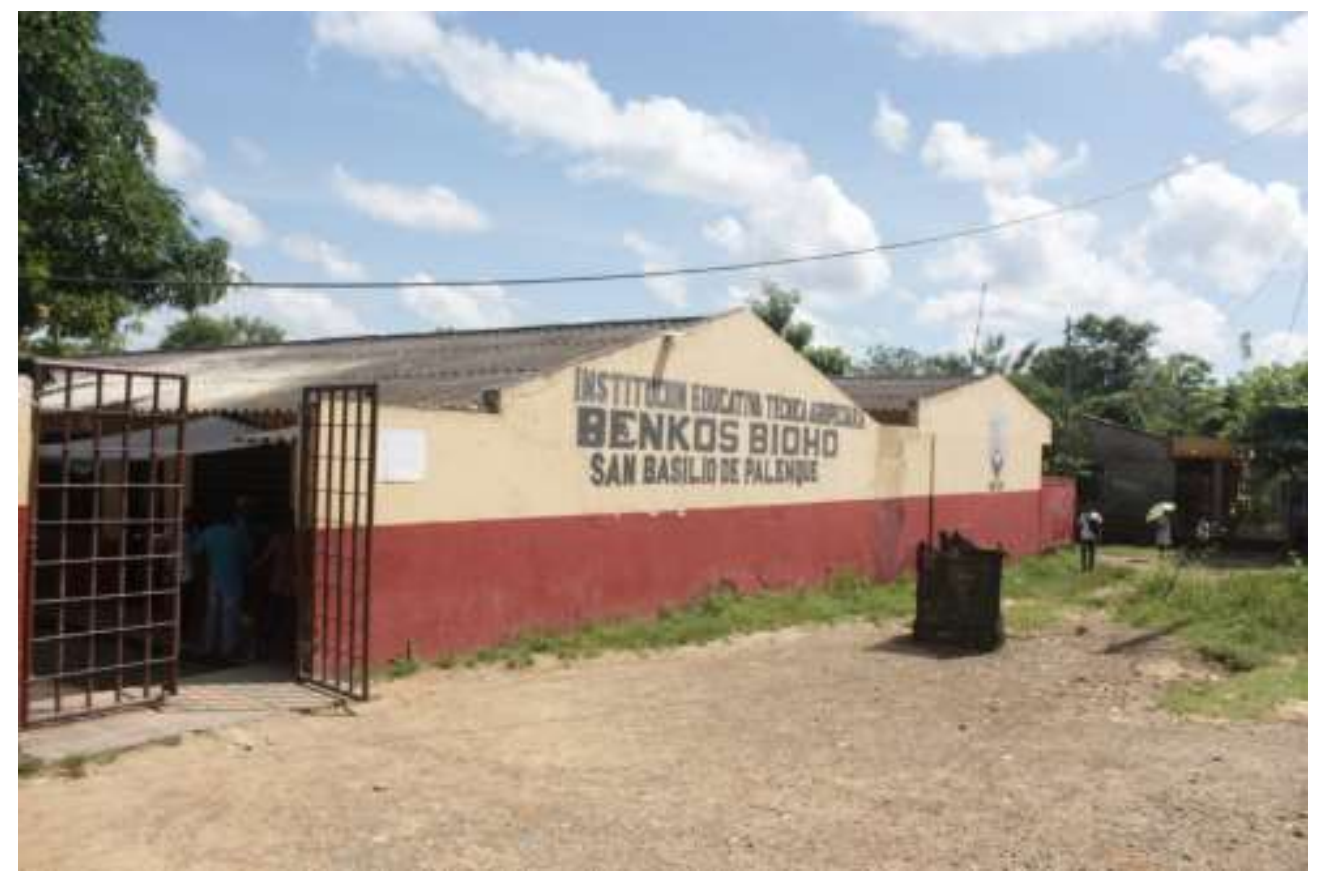

(Foto tomada por: Julia Correa, San Basilio de Palenque, 22 de noviembre de 2016) 
Imagen 4.4: Cartografía social realizada por los niños de San Basilio de Palenque

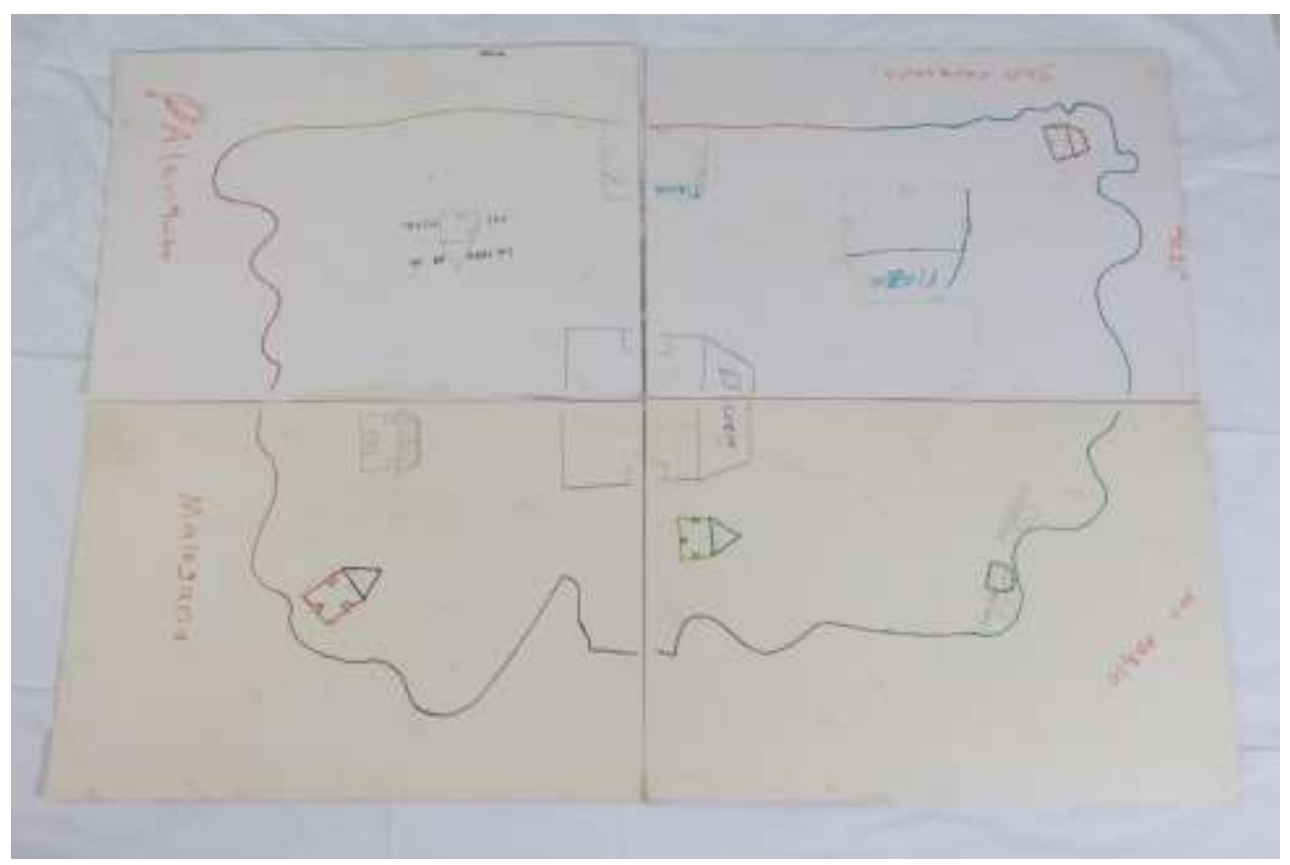

(K. L. Valdes, Y. C. Cañate, J. D. Cañate \& J. E. Cañate, cartografía social, 22 de noviembre de 2016)

\subsection{Aproximaciones al contexto escolar de la Institución Educativa Camino de Paz sede Villa Liliam}

La Institución Educativa Camino de Paz sede Villa Liliam se inauguró en el año 2012 como parte de la oferta de servicios sociales y educativos de la Fundación Las Golondrinas para la Comuna 8, el barrio Caicedo Villa Liliam y vecinos. La Fundación cuenta con más de 35 años de experiencia en el trabajo con comunidades vulnerables de Medellín, parte de estos años dedicados específicamente a esta comunidad.

La construcción de la institución contó con el apoyo económico de diferentes empresas de la ciudad lo que la hace ideal en términos de infraestructura, en la Imagen 4-5 se puede ver la fachada de la institución educativa. 
Imagen 4-5: Institución Educativa Camino de Paz sede Villa Liliam

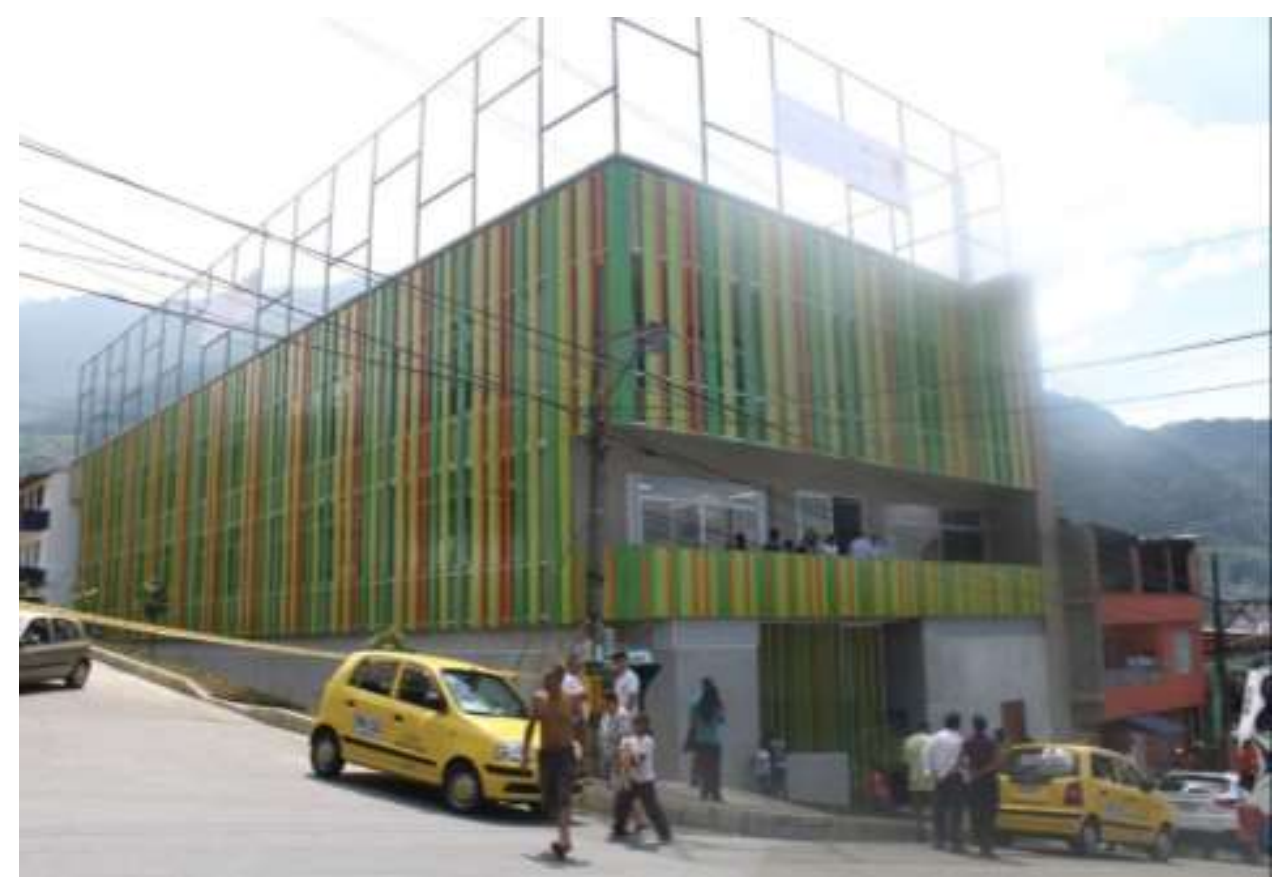

(Foto tomada por: Julia Correa, Medellín, 13 de diciembre de 2012)

Llegar a la institución Camino de Paz sede Villa Liliam es encontrarse con un barrio construido en las laderas de una montaña, con calles mal trazadas y estrechas donde una casa es la base de otra y las busetas transitan a toda velocidad haciendo sentir vulnerables a pasajeros y transeúntes. La institución se alcanza a divisar cuadras abajo, entre las casas, pero no se puede llegar en línea recta, es necesario recorrer algunas calles hacia un lado y hacia el otro para poder llegar a una de sus puertas que justo está en medio de la loma -tiene dos puertas de ingreso-. El barrio Villa Liliam está cerca de Villa Tina, La Sierra y Enciso, y desde el centro de Medellín se puede llegar a él por los barrios Buenos Aires y Caicedo. En Villa Liliam predominan las casas de ladrillo, de uno, dos o hasta tres pisos y hay movimiento permanente: el transporte público, motos y personas a pie. En este sector de la ciudad es difícil identificar donde comienza o termina un barrio, pues todos conservan características físicas similares, comunes en los barrios más vulnerables de la ciudad de Medellín construidos en las laderas de las montañas. En la Imagen 4-6 y en la Imagen 4-7 se visualiza desde la institución educativa la panorámica de Medellín y la panorámica de la montaña, respectivamente. 
Imagen 4-6: Vista hacia Medellín desde la Institución Educativa Camino de Paz sede Villa Liliam

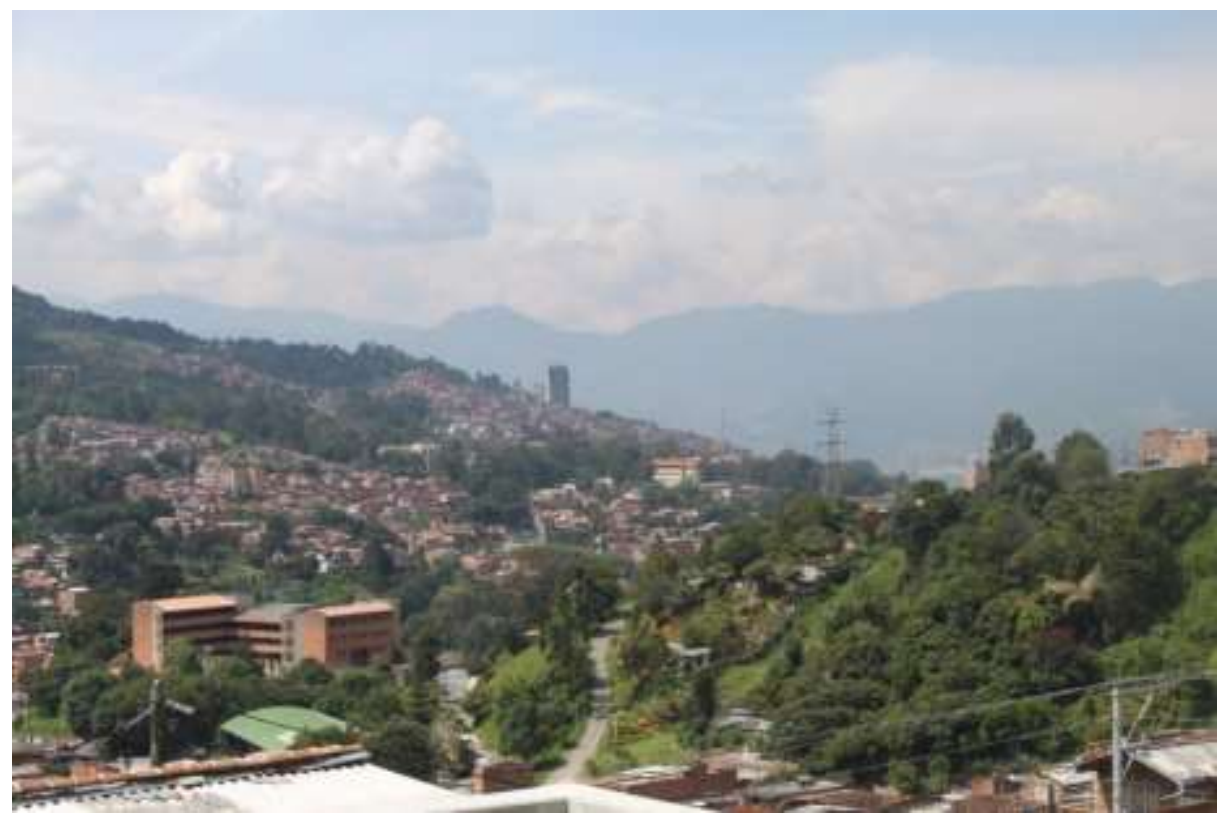

(Foto tomada por: Julia Correa, Medellín, 13 de diciembre de 2012)

Imagen 4-7: Vista hacia la cima de la montaña desde la Institución Educativa Camino de Paz sede Villa Liliam

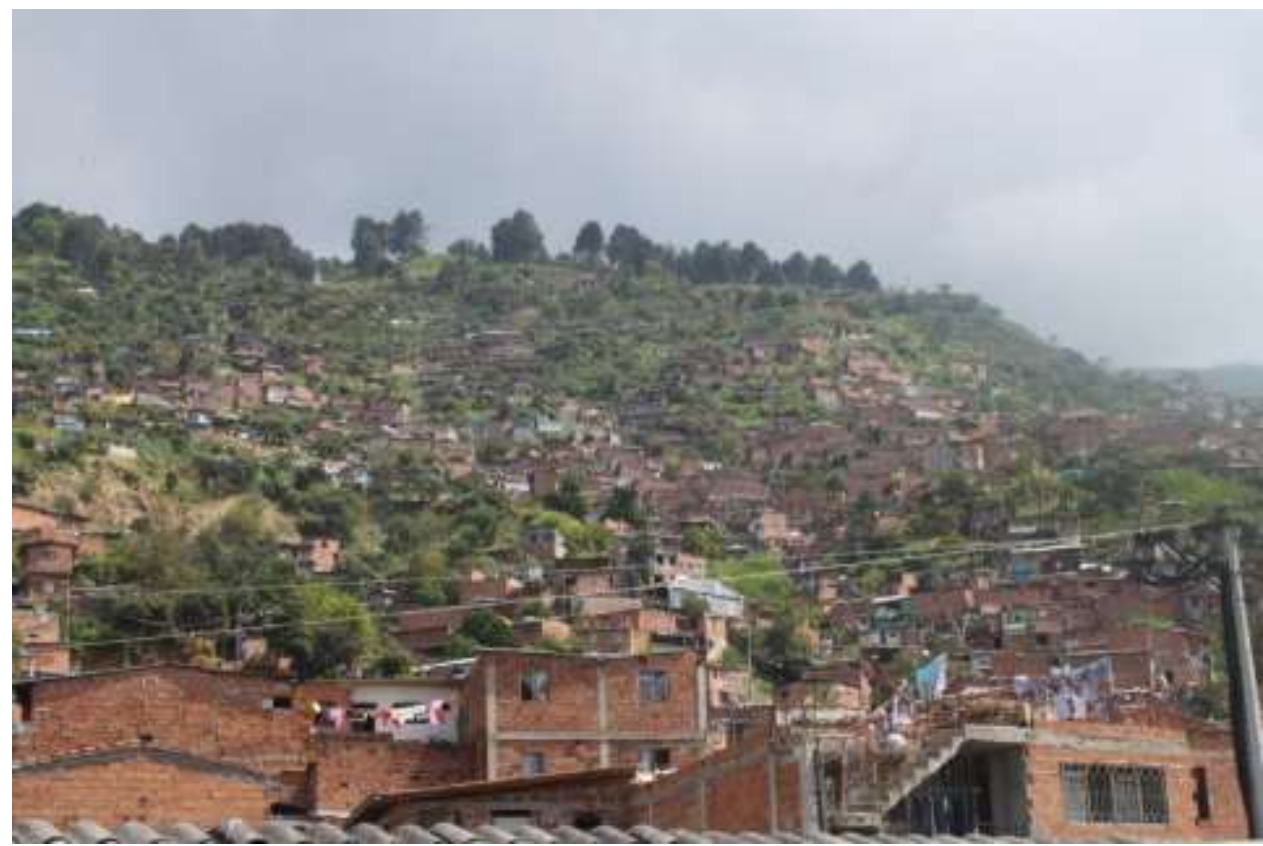

(Foto tomada por: Julia Correa, Medellín, 13 de diciembre de 2012) 
La Comuna 8, Villa Hermosa, donde se erige el barrio Villa Liliam, se fue poblando, entre otras, por procesos de invasión o asentamientos ilegales desde la década del 40, según cuenta Gloria Naranjo Giraldo en el libro Medellín en zonas (1992):

Desde la década del 40 comienzan a generarse asentamientos ilegales por la vía del urbanizador pirata ubicados en áreas periféricas y en algunos casos rurales. Ejemplo de ellos son un sector de Enciso y un sector de El Vergel entre otros en la comuna de Villa Hermosa, y en menor medida en la comuna de Buenos Aires. (Naranjo, 1992, p.96)

Así lo reafirma Sonia Liliana Botero, profesional que ha liderado la implementación del Programa Félix y Susana en la zona: "Caicedo es un barrio que se fue construyendo por familias desplazadas, en gran medida del Urabá antioqueño o el Pacífico colombiano, y por desplazamiento intraurbano" (S. L. Botero, comunicación personal, 31 de mayo de 2016). Ella y las docentes que participaron en la investigación, coinciden en que precisamente el fenómeno del desplazamiento ha hecho de este sector una población con alta presencia de comunidad afro. Trabajar en educación con una comunidad diversa trae sus retos con los que algunos docentes se sienten más identificados que otros:

Yo traigo mis traumas porque yo soy de Urabá y viví todo ese cuento de la violencia, es algo que yo quedé debiendo, me vine desplazada, entonces me identificaba mucho con la comunidad (...) y ponía el ejemplo, si la profe pudo, si la profe estudió en la Universidad, si a la profe le tocó duro, si la profe aguantó hambre (...) entonces ustedes por qué no pueden. Me enamoré del sector, por lo que yo viví, entonces me sentí identificada, por los niños afros también. (L. Uribe, comunicación personal, 23 de septiembre de 2016)

Las noticias sobre el barrio Caicedo Villa Liliam y la Comuna 8 de Medellín están asociadas a hechos violentos, muerte y prostitución; en medio de este panorama el periódico El Tiempo en el año 2014 resalta la labor de la Fundación Las Golondrinas y los Colegios Camino de Paz (sus diferentes sedes) como apuesta para la transformación de la comuna:

Una gran obra llena de color y alegría es lo que se ve ahora en la que era considerada la esquina más conflictiva del barrio Caicedo Villa Liliam. Las risas y voces de los niños serán los sonidos que reemplacen el retumbar de las balas en esta zona de fronteras invisibles en la comuna 8. (Monsalve, 2014) 
Así como lo dice este artículo, las docentes de la institución coinciden con el cambio que ha tenido la comunidad desde que la institución abrió sus puertas, cabe resaltar que era recurrente encontrar a jóvenes que para solicitar dinero paraban los vehículos cuadras antes de llegar a la institución, hoy en día esta situación no se presenta, y aunque el barrio Villa Liliam y los barrios aledaños continúan teniendo situaciones sociales, económicas y ambientales -por deslizamientos de tierras-, complejas, pareciera que ha ido mejorando. "Me dio miedo el barrio, pero entrar a la institución es diferente, tiene una infraestructura muy bonita, y uno se sorprende, uno no espera encontrarse un lugar tan bonito (...) Es un contraste" (S. L. Botero, comunicación personal, 31 de mayo de 2016).

Los niños por su parte, durante la actividad de cartografía manifestaron sentirse tranquilos en las calles del barrio, muchos se desplazan a pie del colegio a la casa. Cabe resaltar que la esquina donde se ubica el colegio, es estratégica en temas de movilidad y transporte público y hay una tienda en la que se venden productos de aseo, alimentos, bebidas y tiene un espacio con máquinas de juego, esta tienda es referente para los niños. Este lugar podría considerarse un foco importante, un espacio donde se encuentran los niños con la comunidad y donde están propensos a recibir lo bueno y lo malo que se vive allí, especialmente llama la atención las máquinas para jugar.

Las docentes manifestaron además, la normalización de la violencia en el sector, afirmaron que para los niños es común ver una pelea callejera, escuchar disparos, ver a una persona muerta violentamente. "Para ellos lo más común es ver que mataron a alguien, esta zona lo tiene como una cultura, 'Profe: usted es muy gallina', yo sí me escandalizo, ellos no" (D. Gómez, comunicación personal, 23 de septiembre de 2016).

En la Imagen 4-8 y en la Imagen 4-9 se presenta el resultado de la cartografía social realizada con dos grupos de estudiantes, uno de niñas y otro de niños, distribuidos de esta manera por ellos mismos. Las niñas se centraron en dibujar sus casas y en describir las actividades que realizan en sus hogares, en contar con quienes viven y si tienen mascotas, resaltaron, además, la existencia de un parque con juegos cerca a sus casas. Durante la explicación del mapa, las niñas expresaron con normalidad las tareas desempeñadas en el hogar y que por sus edades no les corresponden. De manera obligatoria acompañan a sus madres en los oficios domésticos, ellas dicen que cuando tienen tiempo libre en la casa salen a jugar. Que las niñas hagan oficio es una tarea impuesta por la sociedad machista que aún tiene presencia en estos hogares. A este hecho se le suma, la constante de 
hogares conformados por madre - padrastro, padre - madrastra o madres cabeza de hogar; de todas formas pareciera más frecuente la ausencia del padre en la formación de estas niñas, lo que ha deteriorado el vínculo afectivo entre los padres y sus hijas. Rescato la siguiente conversación con tres estudiantes mujeres durante la actividad de cartografía social:

-¿A quién no se quieren parecer? -

A mí papá

A mí papá

No quiero parecerme a mi padrastro

Yo no quiero parecerme a mi padrastro

Yo ni a mi madrastra ni a mi papá

$(\ldots)$

- ¿Por qué no se quieren parecer a ellos? -

Porque son malos

Sí, hay veces que nos pegan mucho, desde pequeños

Y cuando yo vivía con mi papá él no me daba comida

- ¿Por qué no te daba comida?, ¿porque no quería o porque no podía?-

Porque no quería, porque él nada más le daba a mi hermanita, porque él nada más quiere a mi hermanita

(Y. Moreno, S. Giraldo \& L. García, comunicación personal, 3 de octubre de 2016)

En el caso de la cartografía social de los niños, ellos aunque ubican sus casas en el mapa, hacen especial énfasis en los lugares comunes como parques, zonas verdes, la tienda cercana a la escuela. Sus relatos estuvieron relacionados con juegos, deporte y actividades recreativas; esto es una muestra de las diferencias formativas entre niños y niñas, que acentúan aún más el machismo en el que las niñas tienen poco tiempo para las actividades recreativas y para los niños estas actividades son prioritarias. 
Imagen 4-8: Cartografía social realizada por tres niñas.

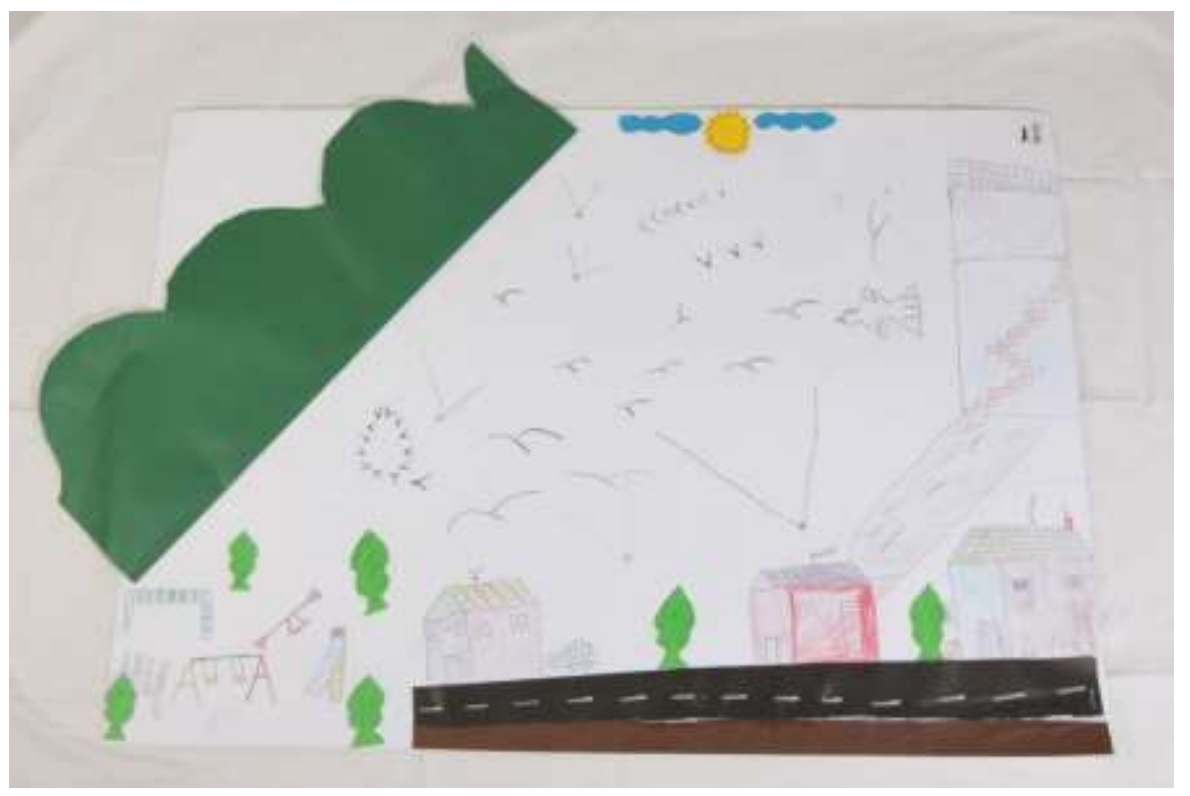

(Y. Moreno, S. Giraldo \& L. García, cartografía social, 3 de octubre de 2016) Imagen 4-9: Cartografía social realizada por cuatro niños.

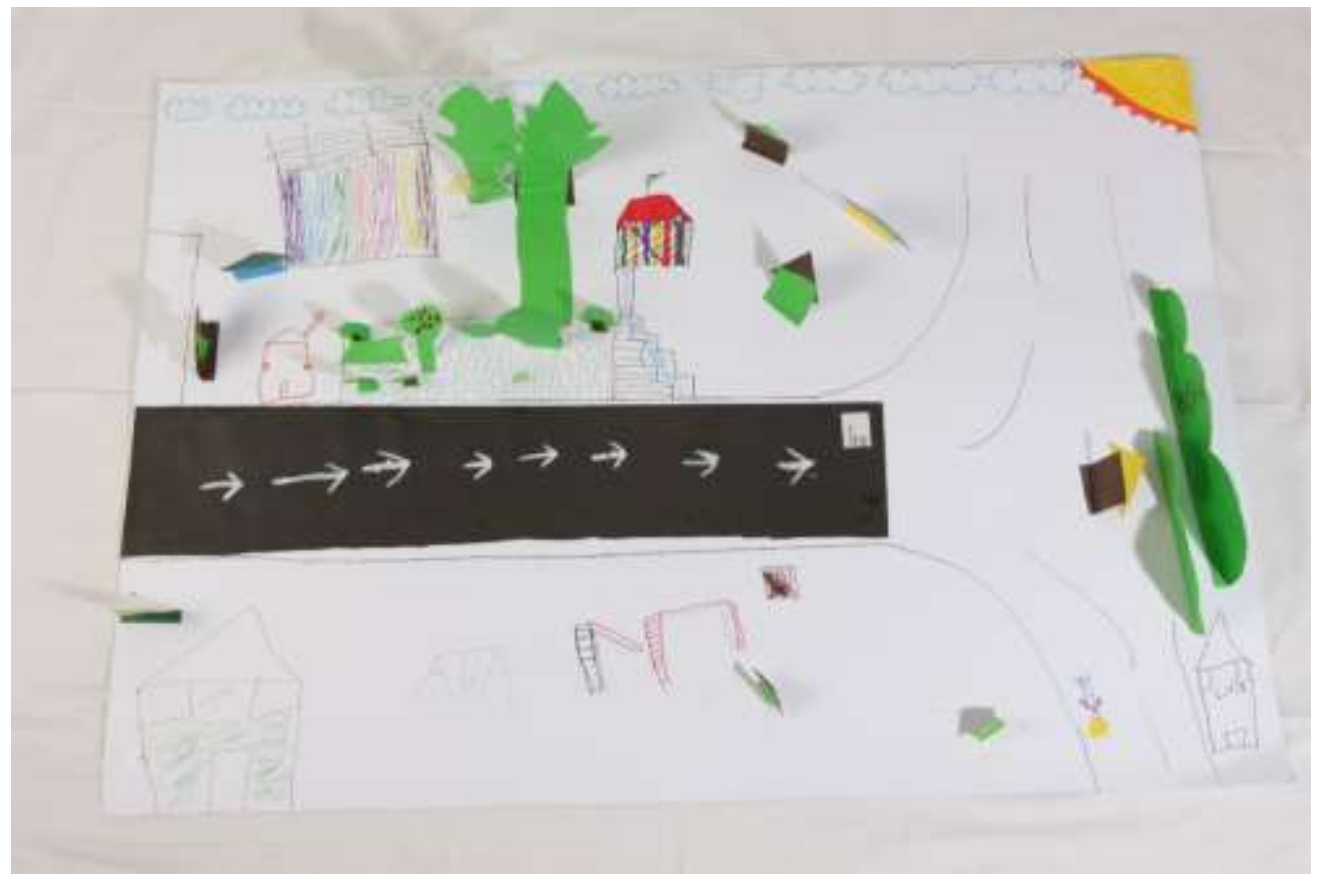

(D. Pérez, S. Toro, S. Correa \& Y. Cardona, cartografía social, 3 de octubre de 2016) 


\subsection{El significado de La Escuela}

En ambas regiones — San Basilio de Palenque y el barrio Villa Liliam en Medellín-, la construcción del significado de escuela está ligada indudablemente a un proceso histórico, que da cuenta de la transformación que ha tenido ésta en los imaginarios colectivos. Muestra de ello es el nombre de las instituciones educativas, en el que en uno se hace referencia a un líder guerrero representativo para los palenqueros (Benkos Bioho); y en el otro, a la necesidad de una población de encontrar escenarios de paz y reconciliación (Camino de Paz). En la definición de estos nombres hay dos intenciones, una la representatividad de la escuela como espacio comunitario que no se limita sólo a ella, y que como lo proponen Longás, Civís, Riera, Fontanet, Longás y Andrés (2008) propenda por una educación que comprometa a la sociedad; y por otro lado, estos nombres construyen identidad, que como lo dice Flores (2007) refiriéndose al territorio y haciendo analogía con la escuela, este es un espacio en el que se desarrollan la vida y los pensamientos de una comunidad, en el que a su vez se construye la identidad.

En ese sentido, para el caso de Medellín el referente de escuela está asociado a procesos de disminución de la violencia y a cómo la población ha ido evolucionando en estos términos. Las fuentes consultadas coinciden en la importancia de la escuela Camino de Paz en el barrio, concebida precisamente como un territorio de paz:

En Caicedo el impacto del colegio es mucho, cuando no estaba el colegio y estábamos en el sector de arriba, casi todo el día era bala. Desde que llegó el colegio, que le hubiera tocado al colegio, tal vez dos veces una balacera, entonces yo digo que hay un impacto, el colegio tuvo que haber logrado algo, la comunidad lo ve como un gestor de paz (...) yo creo que es un trabajo que va permeando la mente de las personas del sector, el colegio se ubica como un lugar de protección donde no sólo puedo acudir por una ayuda sino en un lugar donde capacitan, donde se brindan oportunidades y cosas buenas a toda la comunidad. El cambio ha sido total, el colegio está ubicado en tres puntos donde llegaban todas las balas habidas y por haber y ya eso no se ve. Es bonito uno saber que uno hace parte de eso. (L. Uribe, comunicación personal, 23 de septiembre de 2016)

"La gente del barrio respeta mucho el espacio, uno no ve pelados en las esquinas mal ubicados o con armas o fumando marihuana, es una fortaleza para muchos padres de 
familia, es una bendición tenerla acá" (R. Gutiérrez, comunicación personal, 23 de septiembre de 2016).

En San Basilio de Palenque por su parte, la escuela es un espacio de puertas abiertas y como tal, se convierte en un referente de libertad frente a la permanencia de los niños en la institución educativa durante la jornada escolar, esto se evidencia en aspectos como que la escuela es un lugar sin vigilancia, sin portería, los niños asisten porque quieren, por costumbre, o porque es el lugar donde socializan con otros niños:

(...) acá hay mucha libertad en los niños desde muy pequeñitos, los niños deben ser capaces de ir y venir solos a la escuela, no hay control en la puerta, solamente los niños de preescolar y eso porque los papás los recomiendan, son poquitos (...) como ellos andan así cotidianamente, ellos son capaces de desenvolverse en la comunidad, aquí no hay una celaduría, no hay portero. Los niños sí vienen a clase, de pronto para integrarse con sus compañeros, con el amiguito. Algunos toman esto de manera seria, como que yo quiero aprender algo; pero he visto que la mayoría es para estar con los amigos. (F. Beltrán, comunicación personal, 22 de noviembre de 2016)

El hecho de no tener portería lleva a pensar que Palenque continúa siendo un poblado seguro, con lazos de hermandad arraigados; sin embargo, abre la posibilidad de pensar que los niños y niñas están en riesgo, expuestos a que cualquier vecino o foráneo con malas intenciones se acerque sin mayor dificultad a ellos.

Respecto a los niños, muchos manifestaron sentirse a gusto en la escuela, incluso mucho más a gusto que en la casa, porque aquella es el espacio donde aprenden y donde juegan:

Yo tengo una seño... cuando yo vine para el colegio el primer día que yo fui, que yo no sabía nada, yo me sentí como nervioso, y la seño me comenzó a ayudar hasta que yo me sentí bien en el colegio. (J. Cañate, comunicación personal, 22 de noviembre de 2016).

"A mí me gusta más la escuela, porque en nuestra casa están los padres de nosotros y en la escuela aprendemos a hacer tareas, a sumar, a dividir, a multiplicar y a restar. Aprendemos muchas cosas" (Y. V. Torre \& Y. M. Cañate, comunicación personal, 22 de noviembre de 2016). 
En el barrio Caicedo Villa Liliam en Medellín, llama la atención que para el caso de las niñas, la escuela se convierte en el lugar donde son y actúan como niñas, ya que por el contrario en sus casas deben asumir funciones que no les corresponden, como ayudar a hacer oficios de la casa. Lo normal para ellas es ayudarles a sus mamás a lavar ropa, tender las camas, trapear, arreglar cocina.

Niñas mías cuando eran de seis o siete años, trayendo al hermanito de dos o tres años, o la de 10 responsable del de seis del de dos o hasta de meses. Entonces ellos le delegan muchas responsabilidades a niños que todavía son muy pequeños. (L. Uribe, comunicación personal, 23 de septiembre de 2016)

$Y$ en esa medida se legitima el rol de los maestros, en el que se convierten en referentes de los niños, si la escuela es el territorio donde se sienten bien, el docente es aquel adulto a seguir, con el que se identifican.

Los niños por su parte están motivados a practicar algún tipo de deporte fuera de la escuela o a jugar. Con situaciones como éstas, en las que las actividades de niños y niñas son diferentes al llegar a casa, se perpetúa el machismo en la población, problemática que se ratifica con la tipología de los hogares, donde:

Los pequeños son muy vulnerables, no sé si es por la cultura de la gente... pero ellos permiten muchas cosas, que el papá tenga otra mujer, dos mujeres, que tenga hijos con una y vaya donde la otra, entonces los muchachos se vuelven muy machistas y pierden sensibilidad frente a muchas cosas. (L. Uribe, comunicación personal, 23 de septiembre de 2016)

Aunque en San Basilio, las niñas no manifestaron asumir funciones de este tipo, los docentes sí afirmaron que cada vez existe mayor tendencia a que los niños y niñas asuman funciones que no les corresponden, sobre todo aquellas relacionadas con cuidar a sus hermanos menores:

Algunos niños de 10, 12 años, ya tienen una responsabilidad de cuidar a los hermanitos más pequeños, la verdad es que cuando es así muchos de ellos ya se sienten capaces de formar un hogar, porque si ya están lidiando a los hermanos pequeños, ya cocinan, ya lavan, ya barren, ellos se creen capaces de formar un 
hogar, por eso es que de pronto muchas niñas de acá salen embarazadas. ( $F$. Beltrán, comunicación personal, 22 de noviembre de 2016)

De acuerdo con la investigación de Escalante (1979), esta es una situación que se presenta desde hace años: "El papel de los niños en la organización familiar es considerable, especialmente las niñas mayores a quienes vigila de cerca la madre pues antes de la pubertad está en condiciones de suplirla en los oficios domésticos" (Escalante, 1979, p.58).

Y agrega: "La cantidad de oficios de la madre y el cuidado del lactante determina que los niños se vayan para donde quieran sin que se preocupen mucho por averiguar el paradero, salvo en el momento de acostarse" (Escalante, 1979, p.68).

Cabe resaltar que los docentes entrevistados en las dos instituciones educativas no son ni del barrio Caicedo Villa Liliam ni de San Basilio de Palenque, todos deben desplazarse desde diferentes lugares de la ciudad y desde otros municipios para ejercer sus funciones como docentes en la institución. Y esa es la tendencia en ambas instituciones, en Villa Liliam esto se ha convertido en un punto desfavorable para la continuidad en los procesos y programas como el de Félix y Susana, pues existe mucha rotación dentro del equipo docente, que son por lo general jóvenes profesionales, licenciados, que eligieron ser docentes por gusto y vocación. En San Basilio el equipo docente lleva muchos años en la institución y puede facilitar el desarrollo de Programas, sin embargo, existen varios de estos docentes que fueron nombrados en sus cargos en procesos políticos, incluso algunos fueron nombrados con sólo haber terminado el bachillerato, con el tiempo los docentes han ido cualificando sus saberes. "Un profesor le enseña a escribir, a leer, a compartir con los amigos también, no echar malas palabras, no pelear" (J. D. Cañate, comunicación personal, 22 de noviembre de 2016).

"Si en la escuela nosotros los docentes logramos sacar a un estudiante que quiera respetar, que valore, no veríamos tanta guerra" (D. Gómez, comunicación personal, 23 de septiembre de 2016).

\subsection{Los niños, las familias, los docentes y la escuela}

Autores como Longás, Civís y otros, manifiestan la corresponsabilidad que debe existir entre docentes, familia y comunidad en la educación de los niños y niñas, y es 
precisamente la responsabilidad de las familias la más cuestionada por los docentes que participaron en la investigación.

En la Tabla 4-1 se plasman los testimonios de docentes de la Institución Educativa Camino de Paz sobre el compromiso generalizado de las familias respecto al cuidado y educación de sus hijos, y cómo influye esta situación en el comportamiento de los niños en el aula de clase; en la Tabla 4-2, se encuentran los testimonios de los docentes de la Institución Benkos Bioho sobre este tema.

Tabla 4-1: Testimonios de docentes de la Institución Educativa Camino de Paz

\begin{tabular}{|c|c|c|}
\hline Docente & Relación familias - niños & Impacto en los niños \\
\hline D. Gómez & $\begin{array}{l}\text { "Este ha sido un año de } \\
\text { muchas alegrías pero } \\
\text { demasiadas tristezas que } \\
\text { me ha tocado vivir con los } \\
\text { niños, porque es un grado } \\
\text { donde se ve demasiada } \\
\text { violencia familiar y los } \\
\text { niños vienen y me la } \\
\text { muestran toda aquí al aula" } \\
\text { "Son padres que no les } \\
\text { interesa el niño" }\end{array}$ & $\begin{array}{l}\text { "El ambiente con los } \\
\text { estudiantes es más difícil, la } \\
\text { convivencia. Lo que ellos han } \\
\text { vivido toda la vida en el } \\
\text { hogar, que son maltratados, } \\
\text { ellos creen que yo le puedo } \\
\text { gritar, yo le puedo pegar y si } \\
\text { no quiero trabajar no hago y } \\
\text { cojo las cosas a patadas y } \\
\text { acabo con todo". }\end{array}$ \\
\hline J. Ospina & $\begin{array}{l}\text { “(..) qué hago con el niño, } \\
\text { si llamo a los padres no les } \\
\text { importa, siempre hay una } \\
\text { excusa (...) iqué hace uno } \\
\text { con un niño que está solo } \\
\text { en tantas cosas?, que } \\
\text { emocionalmente recibe } \\
\text { muchas cosas: golpes, } \\
\text { insultos, maltrato } \\
\text { psicológico; cómo hago yo } \\
\text { y más cuando él no se } \\
\text { deja, cuando el mismo niño } \\
\text { no quiere". } \\
\text { "yo sé que desde familia ni } \\
\text { siquiera a la mamá le } \\
\text { importa y viene con la } \\
\text { carga emocional: de una } \\
\text { pela, de un insulto, venir } \\
\text { sin comer (...) si en la } \\
\text { familia no les importa qué } \\
\text { le va a importar el resto". }\end{array}$ & $\begin{array}{l}\text { "Trato de hablarles del } \\
\text { manejo de las emociones. } \\
\text { Que vivan como niños, que } \\
\text { no pueden resolver los } \\
\text { problemas de los papás, pero } \\
\text { ellos tratan de llamar la } \\
\text { atención y muchas veces de } \\
\text { forma negativa". }\end{array}$ \\
\hline
\end{tabular}




\begin{tabular}{|c|c|c|}
\hline & $\begin{array}{l}\text { "(..) podemos hablar muy } \\
\text { bonito, mostrar a Félix y } \\
\text { Susana, pero desde la } \\
\text { familia totalmente todo lo } \\
\text { contrario". }\end{array}$ & \\
\hline M. Zapata & $\begin{array}{l}\text { "La mayor dificultad que } \\
\text { veo son las problemáticas } \\
\text { familiares. Familias } \\
\text { desintegradas, } \\
\text { desplazamiento, la parte } \\
\text { de vivienda, de } \\
\text { alimentación, niños que no } \\
\text { tienen la presencia de } \\
\text { padre o madre y están al } \\
\text { cuidado de tíos o abuelos. } \\
\text { Abandono familiar en niños } \\
\text { de } 7 \text { y } 8 \text { años, ya } \\
\text { expuestos a la parte social, } \\
\text { están más en la parte } \\
\text { social que en la familiar, y } \\
\text { en las mamás hay } \\
\text { tranquilidad frente a esa } \\
\text { situación". }\end{array}$ & $\begin{array}{l}\text { "Todo esto se evidencia por } \\
\text { ejemplo en un niño de } 7 \text { y } 8 \\
\text { años que ya conoce mucho } \\
\text { de los comportamientos de } \\
\text { calle, más que todo en la falta } \\
\text { de normatividad". }\end{array}$ \\
\hline R. Gutiérrez & $\begin{array}{l}\text { "(...) falta de participación } \\
\text { por parte de los padres de } \\
\text { familias, familias muy } \\
\text { ausentes, a muchos de } \\
\text { preescolar yo no les } \\
\text { conozco las mamás, a los } \\
\text { niños los traen otros } \\
\text { familiares. Es una } \\
\text { debilidad porque si no hay } \\
\text { ese apoyo por parte de la } \\
\text { familia uno se queda } \\
\text { maniatado para hacer } \\
\text { muchas cosas, la familia es } \\
\text { la fuente principal de ese } \\
\text { vínculo que te lleva a hacer } \\
\text { cosas. Me he sentido muy } \\
\text { sola por parte de las } \\
\text { familias". }\end{array}$ & $\begin{array}{l}\text { "Lo característico a nivel } \\
\text { general de toda la institución } \\
\text { es la agresividad de los } \\
\text { pelados, en la parte } \\
\text { comportamental, como no } \\
\text { tienen el acompañamiento de } \\
\text { la familia, hacen y hacen y no } \\
\text { pasa nada, a pesar del } \\
\text { acompañamiento } \\
\text { institucional". }\end{array}$ \\
\hline
\end{tabular}

Tabla 4-2: Testimonios de los docentes de la Institución Benkos Bioho

\begin{tabular}{|l|l|l|}
\hline Docente & Relación familias - niños & Impacto en los niños \\
\hline D. Ramos & "El ausentismo en algunos & "Esos niños que tienen \\
& casos de papá y mamá. & los papás lejos, tienen \\
& Anteriormente las madres se & la autoestima muy \\
\hline
\end{tabular}




\begin{tabular}{|c|c|c|}
\hline & $\begin{array}{l}\text { dedicaban a sus hijos y los } \\
\text { papás al monte. La venta de } \\
\text { alegría y de cocadas también } \\
\text { ha existido desde siempre, } \\
\text { porque eso es algo que forma } \\
\text { parte de la cultura, pero las } \\
\text { mamás iban en la mañana y } \\
\text { en la tarde ya estaban acá, } \\
\text { siempre estaban pendientes } \\
\text { de sus hijos. Ahora no, en } \\
\text { algunos casos aquí son } \\
\text { esporádicas, se van en enero } \\
\text { y regresan en abril para } \\
\text { semana santa o se van de } \\
\text { largo y regresan en junio, } \\
\text { algunas no vienen en junio, y } \\
\text { ya van seis meses los niños } \\
\text { con cuidadores (la abuela, la } \\
\text { tía, los hermanos mayores). } \\
\text { Hay unas que se van de largo } \\
\text { todo el año y regresan en } \\
\text { diciembre, es un año que un } \\
\text { niño no tiene la caricia de una } \\
\text { mamá, no tiene un afecto de } \\
\text { un papá, son niños que se } \\
\text { van levantando con esos } \\
\text { vacíos, que más adelante los } \\
\text { reflejan en agresividad, en } \\
\text { mal trato". }\end{array}$ & $\begin{array}{l}\text { baja, bajo rendimiento } \\
\text { académico, } \\
\text { ausentismo, deserción } \\
\text { escolar". }\end{array}$ \\
\hline F. Beltrán & $\begin{array}{l}\text { “(..) poca ayuda de parte de } \\
\text { los papás hacia los niños, } \\
\text { ellos creen que por el hecho } \\
\text { de venir a principio de año y } \\
\text { firmar una matrícula ya. Por } \\
\text { la costumbre de ellos, las } \\
\text { mujeres se van cuatro, cinco, } \\
\text { seis meses a vender, los } \\
\text { niños quedan al cuidado del } \\
\text { papá, pero qué pasa, que ese } \\
\text { papá se va para el monte, a } \\
\text { trabajar lo poquito que tiene y } \\
\text { a traer lo poquito de comida } \\
\text { que puede conseguir en la } \\
\text { finquita. Y los niños quedan } \\
\text { prácticamente huérfanos, sin } \\
\text { papá y sin mamá”. } \\
\text { "(...) no hay una orientación } \\
\text { en la casa y la mayor parte } \\
\text { del tiempo están en la casa”. }\end{array}$ & \\
\hline
\end{tabular}




\begin{tabular}{|l|l|l|}
\hline A. García & "(...) esa es como la crianza & "ellos no guardan esa \\
que aquí reciben, de hogares & diferencia entre un \\
donde se les grita, y como & adulto y un niño, sino \\
eso lo ven desde que & que el trato que ellos \\
nacieron lo hacen con la la es igualitario para & \\
mayor naturalidad". & $\begin{array}{l}\text { todos, y si tienen que } \\
\text { decir una grosería no } \\
\text { miden". }\end{array}$ \\
\hline
\end{tabular}

Estos testimonios dejan claro: que los golpes y el maltrato continúan siendo la estrategia utilizada para reflejar autoridad de padres y madres, que es además una estrategia que durante años fue culturalmente validada por una sociedad, tanto en Palenque como en Medellín; que el abandono es quizá el maltrato más común en los hogares y que éste tiene consecuencias importantes en los comportamientos de los niños; que en los hogares abunda la falta de vínculo afectivo; que hay fallas comunicativas entre la escuela y las familias. La poca comunicación entre ellas acentúa las diferencias en la forma de enseñar conceptos y valores y en la manera como se cría; escasean las estrategias comunicativas en las instituciones que fortalezcan los vínculos y las relaciones, no basta con una escuela de padres que es la herramienta más utilizada en estas instituciones. La familia es el primer entorno protector de niños y niñas, la escuela se convierte en el segundo, por ello la importancia de fomentar relaciones de confianza para lograr identificar casos de abuso, de acuerdo con el planteamiento de Cuadros y Ordoñez (2006).

Los docentes de ambas instituciones educativas estuvieron dispuestos y abiertos a participar de las entrevistas y actividades de la investigación, lo que refleja la necesidad de ser escuchados por un externo, conversaron sin vacilar sobre las situaciones complejas que viven en el aula. En Medellín las expresiones de impotencia y tristeza fueron más reiterativas en las docentes jóvenes que en aquellas con un poco más de experiencia, estas últimas parecen más acostumbradas a las situaciones de agresividad, incluso expresaron que ahora las cosas son mejor que antes o que en otras instituciones es peor. En Palenque todos los docentes tienen más o menos el mismo tiempo de experiencia, por lo que no había mucha diferencia de este tipo, lo que sí manifestaron es cierta discrepancia en cómo eran las cosas antes a como son ahora, el pueblo solía estar más alejado del desarrollo de las ciudades y una de las docentes manifestó que era más notoria antes la autoridad de los padres, por lo tanto los niños eran menos altaneros. 


\subsection{Historias contadas}

La actividad de creación de historias tuvo como resultado conversaciones en las que se evidencia la cotidianidad de las personas que participaron en la investigación y la identificación de experiencias. En el caso de los docentes de ambas instituciones educativas, las historias se focalizaron en situaciones puntuales que viven con sus alumnos. En la tabla 4-3 se referencian las historias contadas por los educadores y en la Imagen 4-10 e Imagen 4-11 se comparten fotografías de la actividad de creación de historias:

Tabla 4-3: Resumen de las historias contadas por los docentes

\begin{tabular}{|l|l|}
\hline Título & Yo quiero pero... no puedo \\
\hline Referente del autor & Mujer (I.E. Camino de Paz) \\
\hline Contenido de la historia & Narra la historia de una niña que era alegre \\
por fuera de clase, pero al entrar al salón \\
de clase cambiaba su actitud, se ponía \\
triste. La docente se acerca a la niña \\
buscando respuestas frente a esa actitud y \\
la niña responde: "(..) solo no tengo \\
cuadernos, no sé escribir y tampoco me \\
gusta leer". La docente busca apoyarse en \\
los familiares para que juntos ayuden a la \\
niña, pero la mamá de la niña le responde \\
a la docente: "Es que ella es muy bruta, y \\
solo sirve para los oficios de la casa". Ante \\
esta respuesta, la docente intenta trabajar \\
el caso desde el salón de clase con la \\
intención de que la niña comprenda que \\
como niña es valiosa e importante.
\end{tabular}




\begin{tabular}{|l|}
\hline Título \\
\hline Referente del autor \\
\hline Contenido de la historia \\
\hline
\end{tabular}

Título

Referente del autor Contenido de la historia
-Sin título-

Mujer de 31 años (I.E. Camino de Paz)

Más que una historia, la docente plasma en esta actividad las expresiones de un niño:

- ¡Huy clase!

- ¡Mi vida, mi mamá,... qué pereza!

- Y ahora qué hago... no quiero nada

- Todos me caen mal

- Y la profe me abraza, no esa señora qué...

- Me dice trabaje en clase y... no...

- A mejor molesto y de malas todos...

- No es que a nadie le importa... entonces um...

- Tengo es hambre...

- No hago nada mejor...

\section{Pedrito y Tomás}

Mujer de 31 años (I.E. Camino de Paz)

La historia de dos niños, uno de ellos al ingresar al salón se tira al suelo, grita, patea y no le hace caso a la docente cuando le pide que vaya a su puesto. Un compañero al ver la situación se levanta de su puesto y golpea a su compañero. Cuando la docente los separa, uno de ellos la agrede física y verbalmente.

Al observar a diario el comportamiento de estos dos estudiantes y al hablar con sus padres, ella se da cuenta que los niños lo que hacen es replicar lo que están viviendo en sus hogares.

\section{Título}

Mi historia familiar

Referente del autor

Mujer de 45 años (I.E. Camino de Paz)

Contenido de la historia
En la actividad la docente plantea diferentes situaciones que vive con sus estudiantes:

1. A la pregunta qué hacen los niños un fin de semana en casa, la respuesta de los estudiantes de preescolar es:

- Dormir todo el día

- Trabajar con el papá para recibir ingresos

- Ir a la iglesia

2. Al pedirle a un niño que dibujara su familia, éste responde que solo va a dibujar a los hermanos que conoce 


\begin{tabular}{|c|c|}
\hline & $\begin{array}{l}\text { 3. Un niño comentando que duerme } \\
\text { en la misma cama con el hermano, } \\
\text { el papá y la mamá, y cuando el } \\
\text { papá llega borracho la mamá lo } \\
\text { manda para el baño. } \\
\text { 4. La situación de una madre que } \\
\text { autoriza a su hijo a llevarse un } \\
\text { juguete que no es de él. }\end{array}$ \\
\hline Título & -Sin título- \\
\hline Referente del autor & Mujer de 43 años (I.E. Camino de Paz) \\
\hline Contenido de la historia & $\begin{array}{l}\text { La docente ilustra las siguientes } \\
\text { problemáticas que vive con sus alumnos: } \\
\text { - } \quad \text { Embarazos a temprana edad. } \\
\\
\text { Sin dejar de ser niñas, pasan a } \\
\text { ser mamás } \\
\text { - } \quad \text { Abuso } \\
\text { - } \quad \text { Maltrato } \\
\quad \text { Violencia, agresión. Falta de } \\
\text { - } \quad \text { Conáctica de valores. } \\
\text { Consumo de drogas }\end{array}$ \\
\hline Título & $\begin{array}{l}\text { No más abuso } \\
\text { Félix y Susana }\end{array}$ \\
\hline Referente del autor & Mujer de 46 años (I.E. Benkos Bioho) \\
\hline Contenido de la historia & $\begin{array}{l}\text { Con la actividad la docente manifiesta su } \\
\text { inconformidad con el ausentismo de los } \\
\text { padres de sus estudiantes en el } \\
\text { acompañamiento de sus hijos, relata que } \\
\text { cuando hace un llamado de atención a los } \\
\text { padres, ellos se justifican diciendo que esto } \\
\text { es algo cultural. }\end{array}$ \\
\hline Título & Por un mundo mejor \\
\hline Referente del autor & Mujer de 52 años (I.E. Benkos Bioho) \\
\hline Contenido de la historia & $\begin{array}{l}\text { En este relato la docente expresa una } \\
\text { problemática que vive con sus alumnos y } \\
\text { es el exceso de información sexual errónea } \\
\text { que consumen sus estudiantes, lo que se } \\
\text { manifiesta en comportamientos } \\
\text { "morbosos" en el aula de clase. } \\
\text { Adicionalmente comenta la situación de } \\
\text { embarazos a temprana edad y el } \\
\text { ausentismo de los padres. } \\
\text { Finalmente comenta la "ofuscación" que } \\
\text { siente porque: "como docente de un } \\
\text { contexto étnico tan marcado como lo es } \\
\text { Palenque uno tiene que mirar desde la } \\
\text { barrera para no ser mal interpretado o } \\
\text { tildado de discriminador". } \\
\text { Finalmente manifiesta que: "no todos los } \\
\text { elementos culturales son buenos, hay que } \\
\text { revisarse y quedarse con lo que realmente }\end{array}$ \\
\hline
\end{tabular}




\begin{tabular}{|c|c|}
\hline & $\begin{array}{l}\text { es bueno y vaya acorde con los tiempos } \\
\text { que vivimos para preservar lo más valioso, } \\
\text { la vida del ser humano". }\end{array}$ \\
\hline Título & -Sin título- \\
\hline Referente del autor & Hombre de 52 años (I.E. Benkos Bioho) \\
\hline Contenido de la historia & $\begin{array}{l}\text { Cuenta la historia de una niña que faltaba } \\
\text { a clase especialmente los días lunes, una } \\
\text { compañera le cuenta al profesor que la } \\
\text { niña no estaba porque se encontraba en } \\
\text { Cartagena comprando droga con su } \\
\text { madre. El docente de una forma prudente } \\
\text { comienza a averiguar y a estar pendiente } \\
\text { de la niña y se entera de que el papá de la } \\
\text { niña ha estado varias veces en la cárcel } \\
\text { por venta de alucinógenos. } \\
\text { El docente concluye que esto es normal en } \\
\text { la comunidad y trata de mantenerse al } \\
\text { margen pues no tiene pruebas de la } \\
\text { situación y la considera bastante delicada. }\end{array}$ \\
\hline Título & Nuestras vivencias diarias \\
\hline Referente del autor & Mujer de 53 años (I.E. Benkos Bioho) \\
\hline Contenido de la historia & $\begin{array}{l}\text { Cuenta sobre los diferentes roles que } \\
\text { tienen los maestros con los estudiantes, } \\
\text { debido en parte por el poco } \\
\text { acompañamiento de la familia, de los } \\
\text { padres que en ocasiones deben } \\
\text { ausentarse del hogar y trabajar por fuera } \\
\text { de la comunidad, ya que en Palenque las } \\
\text { opciones de empleo son muy limitadas. } \\
\text { Habla sobre la ayuda que reciben de } \\
\text { entidades públicas y privadas y de las } \\
\text { diferentes actividades que desarrollan en } \\
\text { clase para motivar el aprendizaje. }\end{array}$ \\
\hline
\end{tabular}


Imagen 4-10: Fotografía del proceso de creación de historias con los docentes

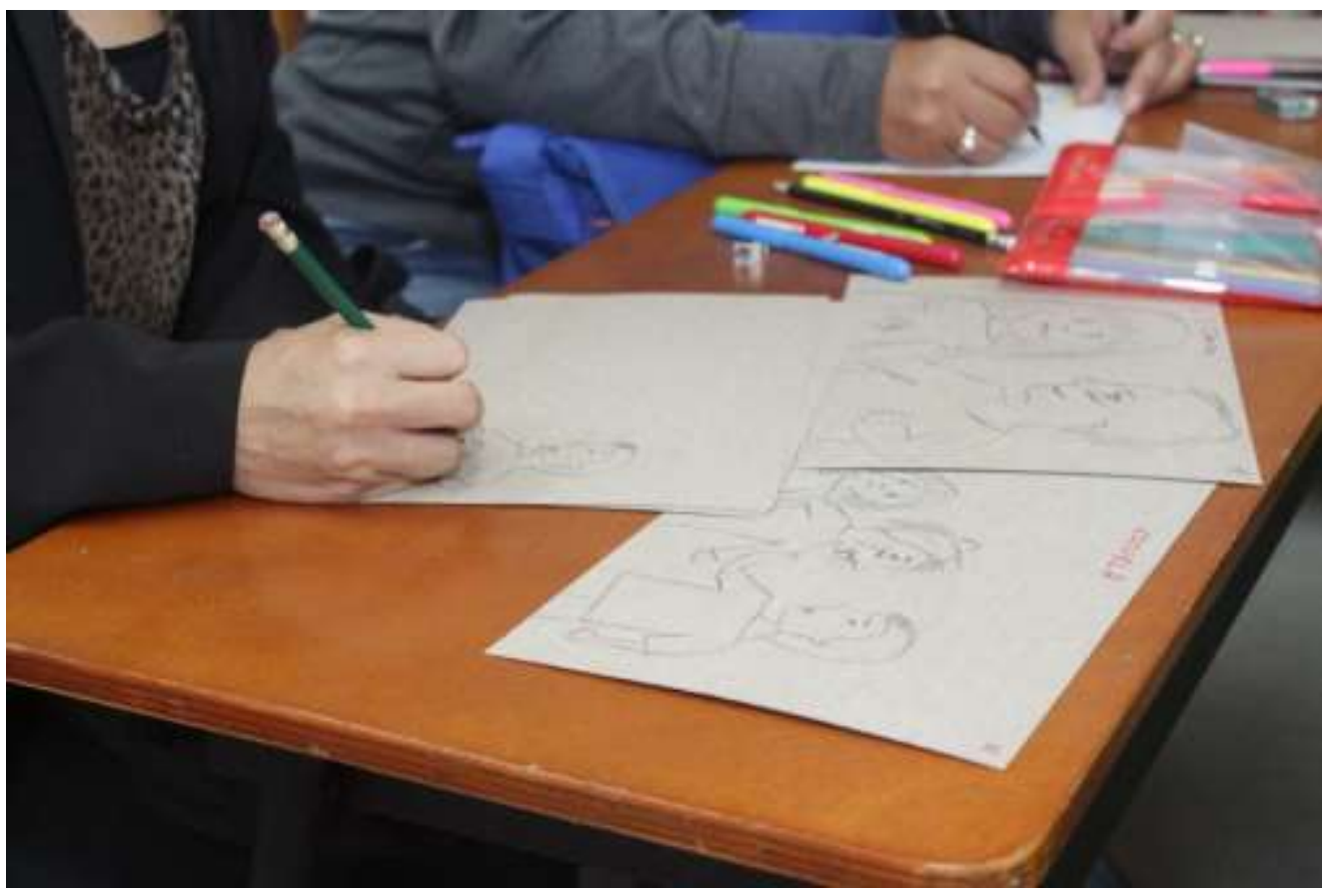

(Foto tomada por Andrés Ángel, Medellín, 23 de septiembre de 2016)

Imagen 4-11: Fotografía del proceso de creación de historias con los docentes

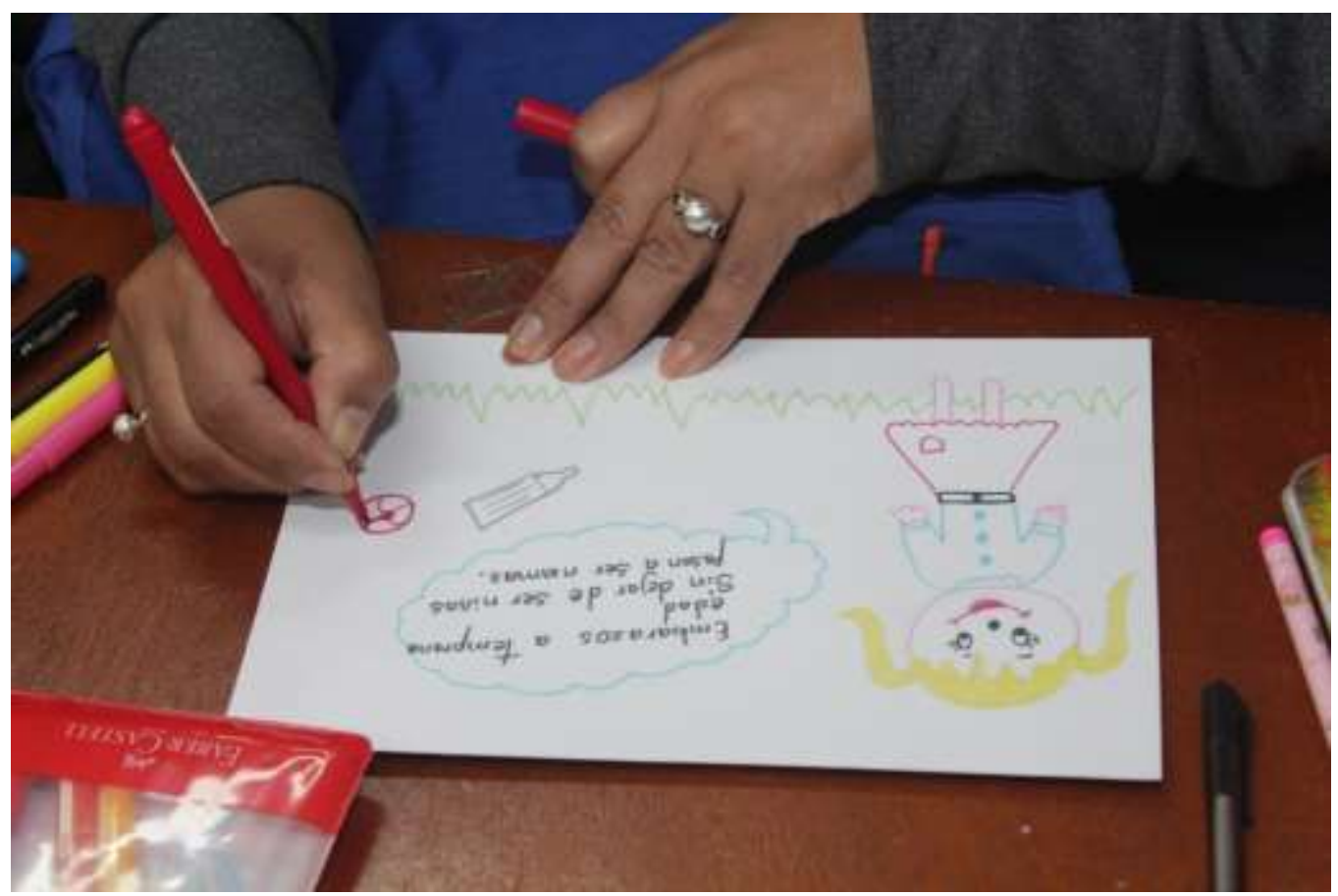

(Foto tomada por Andrés Ángel, Medellín, 23 de septiembre de 2016) 
Las historias de los educadores de ambas instituciones están marcadas por la impotencia que sienten los docentes ante comportamientos y situaciones que se presentan en el aula de clase, pero que trascienden al entorno familiar de sus estudiantes. En esta actividad cobra de nuevo importancia la ausencia de las familias en los procesos de formación de los niños, hecho que tiene mayor gravedad ante la respuesta negativa de la familia frente a la búsqueda de soluciones por parte del docente. La problemática comportamental de los estudiantes es similar en ambos territorios: Palenque y el barrio Villa Liliam; sin embargo, en Palenque las familias encuentran en las características culturales de la población una excusa ante dicha situación y los docentes deben afrontarla con prudencia para no generar síntomas de discriminación. En estas historias salen a la luz además tres problemáticas importantes: el consumo de sustancias psicoactivas, que aunque se presenta en ambos contextos, un docente de Palenque es quien prende las alarmas; los embarazos adolescentes que ocurren en ambos territorios, y con esto la manera como asumen la sexualidad los estudiantes; y la validación de prácticas no adecuadas que son aprobadas por las familias como robar o el trabajo en menores de edad.

Cabe resaltar que en ambas instituciones educativas el docente declara que debe asumir diferentes roles: el de maestro, el de enfermero, el de psicólogo y que a veces se quedan cortos con el conocimiento para asumirlos adecuadamente. Todos identifican que los comportamientos de sus estudiantes son la consecuencia del acompañamiento formativo que han recibido, especialmente en los hogares. Como lo plantean algunos autores, la educación es un asunto de responsabilidades compartidas, en el que el educador no es el único responsable.

Los niños por su parte, recurren a sus propias vivencias a través de la imaginación. En la tabla 4-4 se referencian las historias contadas por los niños y la Imagen 4-12 y la Imagen 4-13 son fotografías de la actividad.

Tabla 4-4: Resumen de las historias contadas por los estudiantes

Título

Referente de los autores

Contenido de la historia

\section{El niño y la mayonesa}

Dos niños de 8 años

(I.E. Camino de Paz)

Narra la historia de un niño de 8 años que estaba jugando un video juego, le dio hambre, llamó a su mamá, se dio cuenta de que su mamá no estaba así que decidió hacerse un sánduche, buscó los 


\section{Observaciones}

Título

Referente de los autores

Contenido de la historia

Observaciones

Título

Referente de los autores

Contenido de la historia

Título

Referente de los autores

Contenido de la historia

Título

Referente de los autores

Contenido de la historia ingredientes, pero al coger la mayonesa ésta se le resbaló y se derramó. El niño se fue para su habitación, al llegar su mamá dijo: "Juan Sebastián qué es este desastre". Y el niño dijo: "Mamá lo siento, sólo tenía que preparar un sánduche". La mamá dijo: "Me limpias ya".

La narración del cuento está acompañada de un dibujo de un niño, un edificio y un letrero que dice: "Mi apartamento"

\section{El colegio y María Alexandra}

Niña de 8 años

Niña de 9 años

(I.E. Camino de Paz)

Cuenta la historia de dos niñas que pelean una y otra vez en el colegio. La pelea incluye agresión física y la profesora debe intervenir para separarlas.

Realizar la actividad con estas dos niñas fue difícil porque estaban distraídas, se evidenciaba que no querían estar allí, se podía ver algo de agresividad en sus expresiones.

\section{La niña del parque}

Niña de 8 años

Niña de 9 años

(I.E. Camino de Paz)

Esta es la historia de una niña que le gusta ir al parque después del colegio, un día se encontró a tres niñas en el parque, ella se sentó en una banca y las tres niñas comenzaron a estrujarla, ella se paró y: "(...) les grito [sic] dejen de molestar yo no les e echo [sic] nada que quieren de mi mi [sic] chulo o mis chanclas". Al final las tres niñas dicen que quieren jugar.

\section{La cultura}

Dos niñas de 8 años

(I.E. Benkos Bioho)

Enumeran los aspectos culturales por lo que se caracterizan como el baile, los peinados, la comida, las plantas medicinales.

\section{-sin título-}

Dos niñas de 8 años

(I.E. Benkos Bioho)

Describen lo que hacen en un día cotidiano en la escuela: van al restaurante, están en 


\begin{tabular}{|l|l|}
\hline Observaciones & $\begin{array}{l}\text { el recreo, juegan, están en clase, } \\
\text { aprenden. }\end{array}$ \\
\hline Título & $\begin{array}{l}\text { En el texto manifiestan que la docente es } \\
\text { amable al igual que sus compañeros. } \\
\text { Referente de los autores }\end{array}$ \\
\hline Contenido de la historia de Félix y Susana \\
$\begin{array}{l}\text { Dos niñas de } 8 \text { años y un niño de } 7 \text { años } \\
\text { (I.E. Benkos Bioho) }\end{array}$ \\
\hline Observaciones & $\begin{array}{l}\text { Cuentan que Félix y Susana son dos niños } \\
\text { que viven en Palenque con su papá y su } \\
\text { mamá, que van a la escuela, que juegan y } \\
\text { son muy felices. }\end{array}$ \\
\hline $\begin{array}{l}\text { En el texto narran el tipo de comida que } \\
\text { consumen (platos típicos). Es curioso que } \\
\text { mencionan que los papás de Félix y } \\
\text { Susana son muy pobres y no les pueden } \\
\text { comprar vestidos y ropa elegante, pero que } \\
\text { igual los niños se sentían muy importantes. }\end{array}$ \\
\hline
\end{tabular}

Imagen 4-12: Fotografía del proceso de creación de historias de los niños

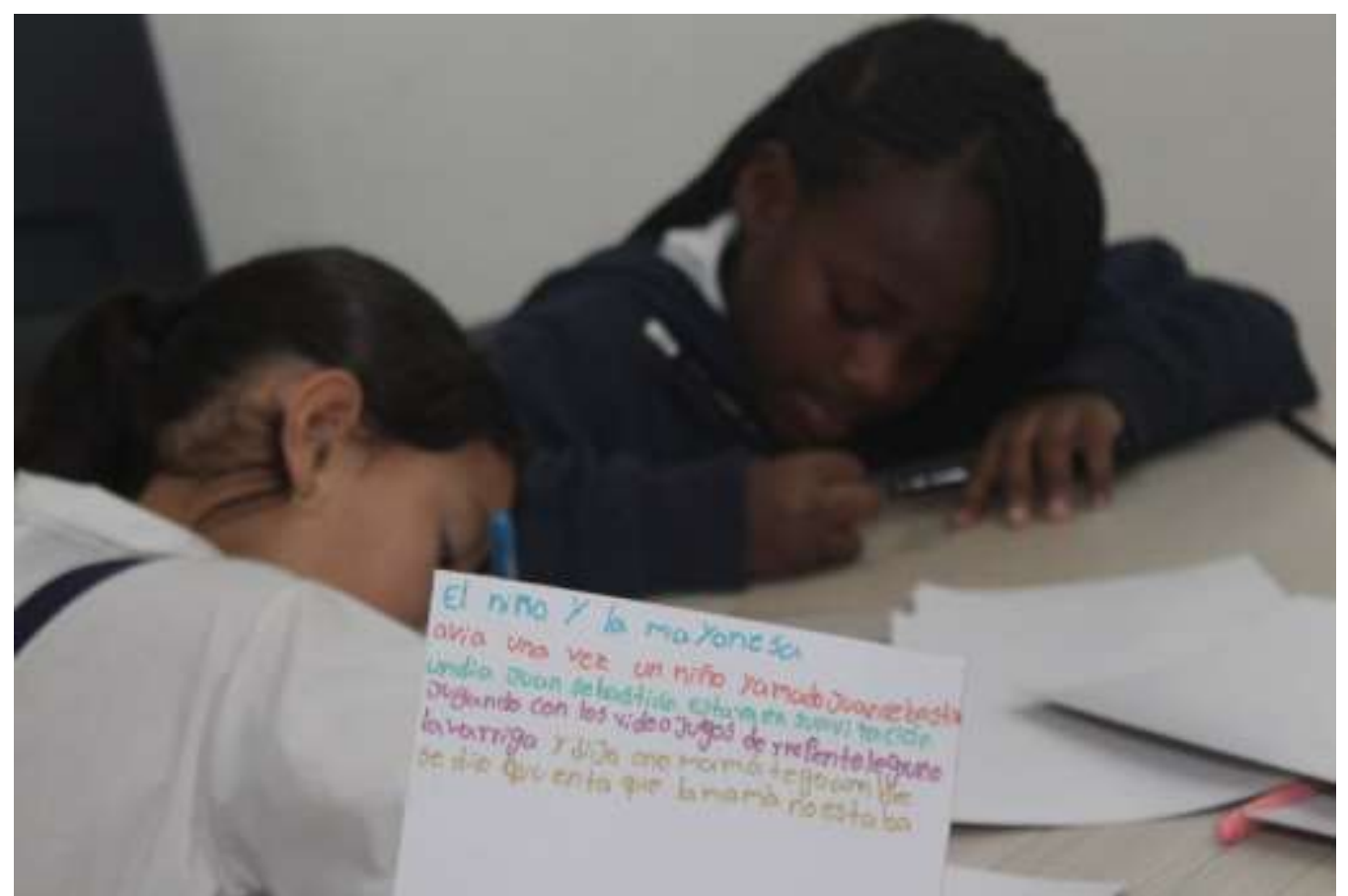

(Foto tomada por Andrés Ángel, Medellín, 23 de septiembre de 2016) 
Imagen 4-13: Fotografía del proceso de creación de historias de los niños

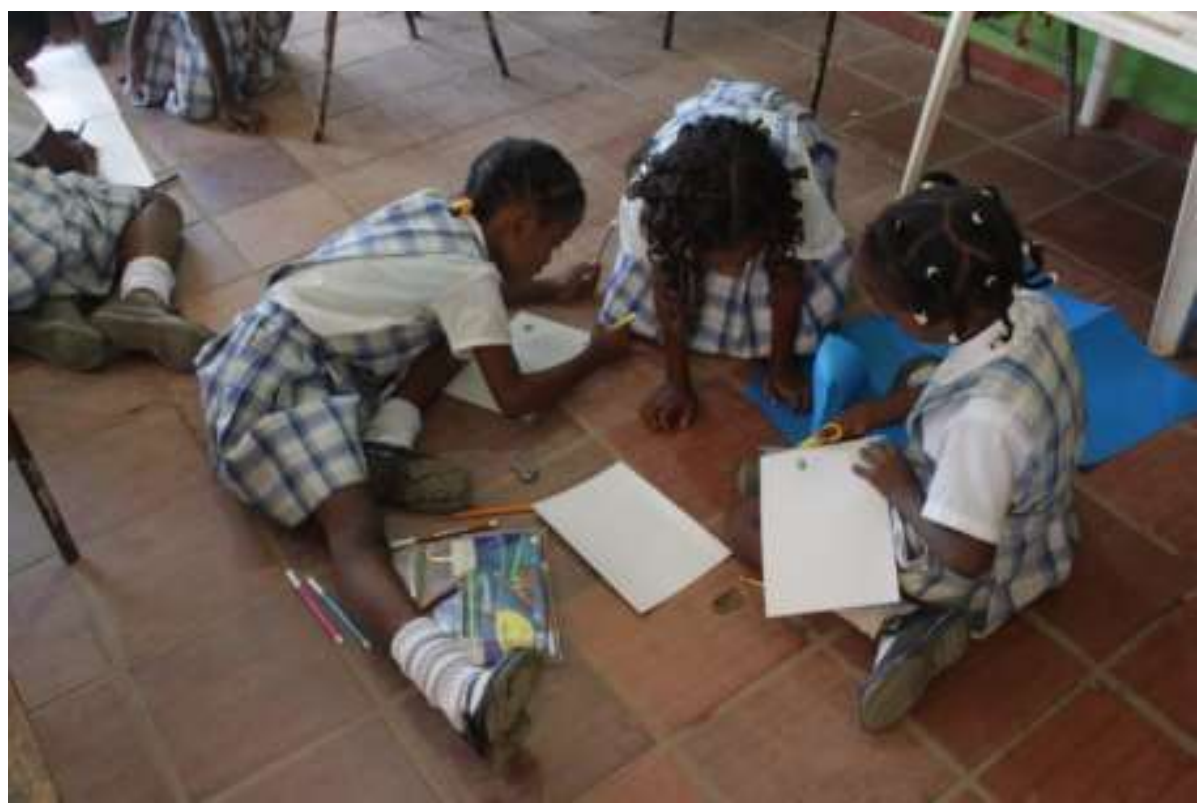

(Foto tomada por Julia Correa, San Basilio de Palenque, 22 de noviembre de 2016)

La actividad de creación de historias en el caso de los niños tuvo bastantes diferencias en Villa Liliam y en San Basilio de Palenque. Para empezar, en Medellín los niños y niñas se distribuyeron en grupos por género, mientras que en Palenque no fue evidente la rivalidad entre género. En Medellín trabajaron dos grupos, dos de niñas y uno de niños, en el caso de las niñas las historias estuvieron basadas en conflictos entre mujeres lo que da muestra de la rivalidad entre ellas mismas, cabe resaltar que inclusive al trabajar con ellas se evidenciaba desde la corporalidad cierto malestar con la actividad. El grupo de niños por su parte, realizó la actividad con entusiasmo, a pesar de que se sentían acosados por las niñas y querían estar alejados de ellas, los niños pudieron referenciar en la historia una situación que perfectamente puede ser de la vida cotidiana, ambos afirmaron jugar videojuegos y hacer actividad física en el tiempo libre, la historia deja claro el papel de autoridad de la madre en estas familias.

Los niños de San Basilio de Palenque referenciaron historias de su vida diaria y especialmente resaltaron sus costumbres, se notó disposición para realizar la actividad y buen trato entre ellos. 
Mientras las docentes de Medellín pudieron dejar a los niños en total libertad de expresión durante la investigación y mantenerse al margen de las actividades con los niños, los docentes de Palenque estuvieron presentes en las actividades, incluso conversaban con los niños, lo que pudo interferir en la libre expresión de sus estudiantes. Aunque la presencia de los docentes durante las actividades no estaba contemplada dentro de la investigación, se determinó no intervenir ni persuadir a los educadores para que dejaran solos a los niños, puesto que este hecho corresponde también al nivel de confianza que se debe tener para dejar a los niños con un extraño. 


\section{Los contextos y Félix y Susana}

Indudablemente los contextos culturales en los que crecen los niños tienen una fuerte influencia en sus comportamientos actuales y futuros. Para el Programa Félix y Susana es importante tener en cuenta dichos contextos ya que, como en el caso particular de esta investigación donde se abordaron dos territorios diferentes, las características culturales marcadas por sus propios devenires históricos hacen que cada niño tenga sus particulares formas de interactuar con él mismo, los otros y el entorno. Félix y Susana es un programa educativo, y tal como lo afirma Freire (2011) la educación no es ajena al contexto, por el contrario debe leerlo y adaptarse a él, sin embargo, y retomando las palabras de dos de las personas que han liderado el Programa Félix y Susana desde sus inicios:

Asuntos como crecer en libertad, la identidad, la salud, la familia, la no discriminación y la educación, que parecen acuerdos universales en cuanto a la niñez, son todavía un reto y una asignatura pendiente que tiene consecuencias en el desarrollo psicosocial, en el bienestar y en la calidad de vida, independientemente del contexto. (Velásquez \& Horta, s.f.)

En ese sentido, Félix y Susana hace su aporte a la educación de los más jóvenes, porque precisamente son ellos quienes comienzan a hacer las primeras preguntas de la vida, y lo hacen desde su condición de humanos, no como parte de una u otra cultura. "En los primeros años abundan las preguntas, la curiosidad por el origen (por ejemplo, ¿de dónde vengo?); asimismo, en esta etapa se presentan experiencias mediante las cuales se reconocen el placer, la identificación sexual, las emociones y los sentimientos" (Velásquez \& Horta, s.f.), facilitar la manera como los docentes, y ojalá las familias, están resolviendo esas preguntas, y con la respuestas adecuadas, eso hace parte del Programa Félix y Susana.

Cabe resaltar las palabras de Álvaro Restrepo, coreógrafo, pedagogo y director del Colegio del Cuerpo de Cartagena de Indias:

Se habla de la educación como una de las herramientas y estrategias más importantes (...) pero no se profundiza en el tipo de educación que estamos necesitando. No es sólo 'educación para el trabajo' lo que requieren nuestros jóvenes: es educación para la vida (y para la paz), para la plenitud, para el 
afianzamiento de nuevos/viejos valores que nos propongan una nueva noción de riqueza, basada más en el ser y en el hacer que en el tener. (Restrepo, 2017)

En el Barrio Villa Liliam en la Comuna 8 de Medellín, el contexto está marcado por la violencia, el desplazamiento forzado, las familias disfuncionales y la reproducción a temprana edad y numerosa:

La cultura de Caicedo es muy arraigada al que pereza, yo no quiero, poca importancia por el estudio. Lo que uno hace dentro de ellos es que entiendan que uno respeta, que hay unos valores, la importancia de formarse para cambiar la realidad que viven, una realidad dura pero que al menos la asuman diferente (...) En Caicedo se ven familias muy separadas, algunas viviendo en condiciones muy precarias. Veo que a las familias no les interesa mucho la educación, la familia manda más al niño es por un pago que les dan porque están estudiando, pero en sí no les interesa que el niño avance. Culturalmente no les importa si el niño saca el bachillerato, porque para ellos la mentalidad es que el niño crezca y se vaya a trabajar en lo que sea. (J. Ospina, comunicación personal, 23 de septiembre de 2016)

A esto se le suma, la costumbre de las personas de sobrevivir bajo las ayudas de entidades públicas o privadas. Respecto a las características de la población:

La mayoría de los niños son desplazados, como una forma de ellos defenderse son los actos agresivos, presentan pobreza, entonces se sienten vulnerables, la respuesta de ellos es un golpe (...) Están muy predispuestos, no sé si piensan que todo el mundo les va a hacer daño. (L. Uribe, comunicación personal, 23 de septiembre de 2016)

En este contexto de Villa Liliam, el material de Félix y Susana sirve para hablar del cuerpo, del autocuidado, del respeto, de las relaciones con el otro y de los valores; aquí Félix y Susana funciona porque las docentes hacen que así sea y lo adaptan a sus necesidades "El material es un pretexto para mejorar la convivencia y fortalecer la autoestima, crear un escudito de protección de ellos hacia lo que los rodea" (L. Uribe, comunicación personal, 23 de septiembre de 2016), para las docentes queda un vacío y es el trabajo con las familias "Falta es la parte de cómo motivar a las familias, el material se presenta para 
trabajar con niños y familias, pero cómo se motiva a la familia" (J. Ospina, comunicación personal, 23 de septiembre de 2016).

En San Basilio de Palenque el contexto habla de preservar las tradiciones culturales, de conservar la esencia de lo que han sido, de reconocerse como el primer pueblo libre de América. Para la docente Ana Lucía García:

Este es un contexto marcado por los temas culturales, entonces al colegio lo atiborran con una excesiva programación, todo el mundo aquí quiere implementar proyectos y programas, y en el centro está la institución, de aquí para allá, no se termina de implementar un programa cuando ya viene otro (...) creo que para un programa como Félix y Susana se debe tener en cuenta el contexto y la cultura, el problema de la sexualidad, la violencia, la convivencia entre ellos es marcado, porque ellos hablan de libertad, tienen muy marcada la palabra libertad, pero a veces esa libertad es mal interpretada porque algunos la consideran como la capacidad para hacer lo que yo quiera, sin importar o tener en cuenta el derecho del que viene detrás. (A. García, comunicación personal, 22 de noviembre de 2016)

En este contexto de San Basilio de Palenque, Félix y Susana les habla del cuerpo, del cuidado y el autocuidado, del respeto y la convivencia:

Con Félix y Susana se trabaja la parte de prevención, porque aquí a Palenque llega mucho forastero, a veces los niños que andan por ahí, los pelados salen y se ven con forasteros y ellos en medio de su inocencia (...) los invitan por un reportaje, una foto, les brindan dulces, uno no sabe más allá algunos que otra intención puedan tener, ahí uno aprovecha con Félix y Susana y trabaja la parte de prevención sin necesidad de decirles cuidado con el que llega, porque no todos llegan con malas intenciones. (D. Ramos, comunicación personal, 22 de noviembre de 2016)

En Palenque reclaman más acompañamiento presencial del Programa y formación constante para que la escuela ofrezca mejores respuestas a las inquietudes de los niños y tenga más elementos para manejar casos difíciles. 
En uno y otro contexto las problemáticas terminan coincidiendo y un programa que aborda temas inherentes al ser, como el conocimiento y reconocimiento propio y de los demás, termina siendo valioso en cualquier territorio, siempre y cuando los docentes, el principal vehículo de Félix y Susana para llegar a los niños, actúen en contexto y en sintonía con el Programa.

(Félix y Susana) Contribuye además a que los niños desarrollen una relación saludable con su cuerpo y establezcan relaciones de respeto y cuidado; promueve a la escuela y, principalmente, a la familia como entornos protectores en el que, además del proceso educativo, se identifique y prevengan situaciones de abuso y maltrato y se generen procesos de resiliencia. (Fundación SURA, 2016) 


\section{Conclusiones y recomendaciones}

\subsection{Conclusiones}

La carencia de afecto, el machismo, la violencia intrafamiliar, el poco acompañamiento de las familias en los procesos formativos de los niños y las familias disfuncionales, son las grandes problemáticas que se evidencian con esta investigación.

Los niños de Palenque así como los de Medellín se crían con el vecino, en la calle, sin madres. Unas están ausentes estando presentes en cuerpo, porque no les importan sus hijos; otras porque deben ausentarse del hogar en busca de trabajo. Pero en ambas regiones la conclusión es la misma: el abandono de la infancia. Tal vez están menos expuestos los de Palenque, porque se sienten ricos, en creencias y costumbres, se sienten seguros con su gente, "Los pobres son como personas normales, pero no tienen plata para comprar comida, pero sí tienen una casita y un techito donde dormir, nosotros no somos pobres", dice Cindi, niña palenquera. Pero esa misma cultura de la que se sienten orgullosos puede ir en contravía cuando el espíritu de libertad de sus antepasados con el que crecen los niños -"El grupo de rebeldes negros de origen africano que rechazaron la esclavitud y se fugaron hacia montes, ciénagas y lugares inaccesibles (...)" (Friedemann \& Patiño, 1983, p.18)-, un espíritu que no se enseña, se lleva guardado en lo más profundo de sus raíces, se acentúa irrespetando al otro, en contra de las normas básicas de convivencia. En Medellín los niños están más expuestos a situaciones de abuso y maltrato por el fácil acceso a una tecnología mal utilizada, a información no adecuada para ellos, a personas mal intencionadas, a los vicios que trae consigo una ciudad grande.

Esta investigación deja al descubierto, además, cómo el comportamiento de los adultos afecta considerablemente el desarrollo de los niños, sus formas de actuar y de pensar. El lenguaje corporal y verbal lo evidencia, pareciera increíble que la persona a la que no se quisiera parecer una niña de 8 años sea su propio padre, ¿cómo es el comportamiento de este hombre al que su hija no admira, sino todo lo contrario? Niñas de 8 años hablando de denuncias a Bienestar Familiar y de los oficios de la casa que deben hacer al llegar a su hogar luego de salir del colegio. 
En temas de crianza se ha dicho mucho que el ejemplo es una de las mayores fuentes de aprendizaje de un niño en formación, y por el ejemplo y las actitudes que se replican de generación en generación se han instaurado los golpes y el maltrato en los hogares de esta sociedad. El abandono es también maltrato, y este parece ser el que más predomina en los hogares, no importa si es en Palenque o en Medellín, el abandono es igual aunque las causas sean distintas. Luchar en contra de ese abandono es una tarea majestuosa que implica la formación de padres y madres en pautas de crianza y la generación de fuentes de ingreso flexibles para madres y padres en las que se les permita tener mayor presencia en el hogar, esto podría ir incluso en contra del desarrollo laboral y profesional de la mujer y del hombre. Indudablemente este tema exige un cambio en la comunicación en el hogar y en la comunidad, con propuestas que incentiven la generación de lazos afectivos. Esto de alguna manera tiene implicaciones en los territorios y las culturas con las que la población se identifica, en Palenque culturalmente las mujeres abandonan el hogar en busca de una mejor calidad de vida, en Medellín el caso podría ser el mismo, el tema está en validar comportamientos que atenten contra la formación de niños y niñas simplemente por ser algo cultural sin tomar medidas que mitiguen las consecuencias de esas acciones.

La investigación revela que los niños sí se quieren parecer a los docentes que los acompañan, algo bueno están haciendo estas personas que se vuelven referentes de sus estudiantes. Y los docentes son conscientes de las dificultades a las que se enfrentan todos los días y buscan en programas como el de Félix y Susana conocimiento que les ayude a sobrellevar las situaciones del aula. Sin embargo, aunque se dispongan bases que propendan por una mejor realidad para niños y niñas y los docentes se preparen para el contexto en el que crecen sus alumnos, lo cierto es que en las instituciones educativas no saben cómo enfrentar el desinterés de las familias y las estrategias se quedan cortas.

Dentro del proceso comunicativo la escucha tiene un papel fundamental que en ocasiones se olvida al darle más relevancia al acto de emitir mensajes; bajo esta perspectiva y con el panorama diario de los maestros, la investigación revela la necesidad de los docentes de ser escuchados por un externo a la institución, quizá para ellos es una manera de hacer catarsis. Para esta investigación sus testimonios se convierten en fuente de información que plantean retos para la implementación del Programa y para los procesos comunicativos con sentido educativo que se llevan a los territorios. Los testimonios de los 
educadores muestran que hay sensibilización en el cuerpo docente frente al tema de abuso y maltrato infantil.

Parece claro que en temas de prevención, tratamiento y restitución de los derechos de los niños y niñas hay mucho por hacer, y que los esfuerzos actuales no son suficientes, porque los niños y niñas continúan siendo vulnerados. Allí la consolidación de estrategias de divulgación social del conocimiento a través de propuestas comunicativas tienen todo el campo de acción. En Colombia existen personas y entidades expertas en estos temas, pero requieren llevar sus conocimientos al común de la gente. En ese sentido Félix y Susana tiene todo por hacer, pero también encuentra allí su más grande vacío, la falta de estrategias de comunicación encaminadas a un cambio de comportamiento de la sociedad. No es suficiente con la formación y acompañamiento a educadores e instituciones educativas, la magnitud del tema requiere acciones de mayor alcance.

Ya hay un camino recorrido y, con éste, Félix y Susana tiene el primer paso listo que es el reconocimiento como Programa que aborda estos temas. Si Félix y Susana es el vocero que legitima, es urgente encontrar los medios adecuados que permitan llevar el mensaje a la población, sin olvidar los canales pensados para la escucha de aquellos que necesitan contar sus historias. Esta investigación se convirtió precisamente en una herramienta para escuchar.

El comunicador como garante del proceso de comunicación es el llamado a poner a circular estos temas en cada territorio, no importa si es en Palenque o en Medellín, para que en un futuro las historias que se recopilen dejen en mejor situación a niños y niñas. La comunicación enfocada al desarrollo y bienestar humano y al cambio en el comportamiento de las personas tiene sentido, cuando se parte de comprender la realidad en la que estas viven. En esa comprensión de la realidad surgen un sinnúmero de particularidades que complejizan las acciones comunicativas y educativas, por eso la mirada crítica de la comunicación siempre será un valor agregado. En esa perspectiva, la Maestría en Comunicación, Desarrollo y Cambio Social aporta a esta investigación desde la mirada crítica del comunicador, formado para ser un mediador social que se desempeña en contextos particulares bajo la búsqueda constante del bienestar humano. La investigación y la Maestría son en sí un ejercicio de reflexión del comportamiento de los seres humanos inmersos en una sociedad, con la comunicación presente como medio y fin. 
Los programas que se desarrollan en diferentes lugares de un mismo país sí deben tener en cuenta los diferentes contextos a la hora de implementarse, para garantizar la adecuada interpretación de mensajes y conceptos; pero también es cierto que, si los programas abordan temas que son inherentes a cualquier persona, como la sexualidad y la identificación y manejo de las emociones, se deben implementar sin importar las características culturales, porque las problemáticas en las regiones se repiten, con diferencias pero con la misma esencia. El desafío está en la formación y cualificación docente, en su preparación técnica y emocional para enfrentar en campo lo que la teoría no enseña y, en el caso de Félix y Susana, ubicar a la familia en un rol relevante para alcanzar mayores niveles de coherencia entre lo que se enseña en la escuela y lo que se aprende en la casa, y lograr mitigar la multiplicación de abandono que se transmite de generación en generación.

El barrio Villa Liliam y el corregimiento de Palenque tienen características culturales diferentes que se deben considerar a la hora de desarrollar estrategias comunicativas focalizadas para cada región, pero que en términos de la ejecución del Programa Félix y Susana y los temas que aborda, no representan cambios significativos en su modelo de implementación, más allá del conocimiento que debe tener el docente sobre las características del lugar en el que enseña.

Esta investigación es el resultado de una propuesta que pone a conversar la empresa y la academia, en la que ambas se nutren del conocimiento y experiencia de la gente que habita Palenque y Villa Liliam.

\subsection{Recomendaciones}

El vínculo madre e hijo se crea desde el vientre, se reafirma durante la lactancia y se formaliza con la presencia constante y duradera de la madre, especialmente en los primeros dos años de vida del niño. Y entonces... ¿qué está pasando con estas madres? Es la primera pregunta que surge de las conclusiones de esta investigación, ¿qué pasa con las familias que se les está volviendo costumbre dejar el cuidado de sus hijos al vecino o a la calle? 
Como complemento a esta investigación y para profundizar en esta problemática se propone realizar una investigación específica del entorno familiar, de las características que conforman los hogares en Palenque y en el barrio Villa Liliam, para entender cómo se educa en la casa y comprender por qué la educación en el hogar va por un lado y la educación en la escuela por otro totalmente diferente, abordando de esta manera los dos principales ambientes en los que crece un niño: la escuela y la familia.

Una vez conocido el contexto en el que crecen niños y niñas, el paso a seguir para la consolidación de una propuesta de divulgación del conocimiento por medio de estrategias comunicativas, es una investigación que permita identificar los medios de comunicación apropiados para llevar los conocimientos en prevención, tratamiento y restitución de derechos a dichos contextos, una propuesta que se salga del aula de clase, porque según vemos, el alcance allí se queda corto.

En cuanto al Programa Félix y Susana, es necesario considerar a la familia como un público relevante, llevándole contenidos que refuercen lo que los niños aprenden en clase. Vale la pena generar estrategias que motiven a los docentes a interactuar con Félix y Susana en sus aulas, a crear nuevos materiales, para no caer en la monotonía; e incrementar la divulgación de conocimiento de expertos en temas de convivencia, pautas de crianza, sexualidad, esto en diferentes formatos, pero considerando las dificultades de acceso a algunas herramientas tecnológicas, por ejemplo.

Al llegar a las instituciones educativas el Programa debe aclarar que no es una tabla de salvación, que a veces tiene más preguntas que respuestas, que el conocimiento se construye entre todos y que Félix y Susana lo lideran los docentes en sus aulas, para que las expectativas no superen los resultados y los docentes no se sientan solos. 


\section{A. Anexo: Fichas de actividades}

Ficha 1: Actividad para niños 1.

\begin{tabular}{|l|l|}
\hline Nombre de la actividad: & Creación de historias \\
\hline Público: & Niños entre 7 y 9 años \\
\hline Objetivo: & $\begin{array}{l}\text { Esta herramienta tiene como base uno de los } \\
\text { materiales educativos del Programa Félix y Susana } \\
\text { llamado No más abusos, que consiste en contar } \\
\text { historias de maltrato o abuso infantil a través de } \\
\text { historias ilustradas en cinco cartones. Se recurre al } \\
\text { uso de esta herramienta porque es el punto de } \\
\text { partida para escuchar a los niños, es una excusa } \\
\text { para generar conversaciones a partir de las } \\
\text { historias que los niños puedan contar (por qué se } \\
\text { te ocurrió esa historia, te ha pasado alguna vez, } \\
\text { con quién vives, qué haces en la casa, qué pasa } \\
\text { en la escuela, etc.). }\end{array}$ \\
\hline Metodología: & $\begin{array}{l}\text { El curso se divide en grupos de tres o cuatro } \\
\text { personas, se les entrega cinco cartones en blanco } \\
\text { y se les da las indicaciones para que dibujen y/o } \\
\text { escriban una historia. Cada cartón corresponde a } \\
\text { una escena. } \\
\text { Deben elegir el escenario de la historia entre: } \\
\text { La casa: la sala, el cuarto, la cocina... } \\
\text { La escuela: el salón, el comedor, el }\end{array}$ \\
$\begin{array}{l}\text { baño... } \\
\text { Lugar del barrio: la tienda, el parque... }\end{array}$ \\
$\begin{array}{l}\text { Tema: Situaciones cotidianas } \\
\text { Motivar para que en la historia haya interacción } \\
\text { con otros, haya algún conflicto, los personajes } \\
\text { deben tomar decisiones. }\end{array}$ \\
\hline
\end{tabular}

Ficha 2. Actividad para niños 2.

\begin{tabular}{|l|l|}
\hline Nombre de la actividad: & Cartografía social \\
\hline Público: & Niños entre 8 y 12 años \\
\hline Objetivo: & $\begin{array}{l}\text { Esta herramienta tiene como objetivo identificar } \\
\text { aquellos lugares cercanos a la institución educativa } \\
\text { que influyan o puedan llegar a influir en el } \\
\text { desarrollo de los niños (parques, tiendas, etc.), se } \\
\text { convierte además en excusa para conversar sobre } \\
\text { aquellos otros actores de la comunidad con } \\
\text { quienes se relacionan, la cercanía de sus viviendas }\end{array}$ \\
\hline
\end{tabular}




\begin{tabular}{|l|l|}
\hline & $\begin{array}{l}\text { con la escuela; para identificar los otros espacios } \\
\text { en los que conviven los niños aparte de la escuela. }\end{array}$ \\
\hline Metodología: & El curso se divide en grupos de tres o cuatro \\
& personas, se les entrega un pliego de papel en el \\
& que deben dibujar el mapa del barrio, ubicando la \\
& escuela como lugar central. ¿Qué lugares hay \\
& alrededor?, ¿qué pasa en cada lugar?, ¿dónde \\
& viven ellos? \\
& Deberán explicar luego el mapa. \\
\hline
\end{tabular}

Ficha 3. Actividad para niños 3.

\begin{tabular}{|c|c|}
\hline Nombre de la actividad: & Encuesta \\
\hline Público: & Niños entre 7 y 12 años \\
\hline Objetivo: & $\begin{array}{l}\text { Conocer a profundidad lo que piensa el niño de la } \\
\text { escuela y de su hogar, conocer su proyecto de } \\
\text { vida. }\end{array}$ \\
\hline Metodología: & $\begin{array}{l}\text { Se le entregará a cada niño una hoja con la } \\
\text { siguiente información para que la diligencie: } \\
\text { Nombre: } \\
\text { Institución educativa: } \\
\text { Curso: } \\
\text { Preguntas sobre la escuela: } \\
\text { ¿Para ti qué significa tu escuela? } \\
\text { ¿Qué es lo que más te gusta de tu escuela? } \\
\text { ¿Qué es lo que menos te gusta de tu escuela? } \\
\text { ¿Quiénes conforman tu escuela? (estudiantes, } \\
\text { profesores...) } \\
\text { ¿Qué es lo que más disfrutas hacer en la } \\
\text { escuela? } \\
\text { ¿Qué es lo que menos te gusta hacer en la } \\
\text { escuela? } \\
\text { ¿Qué hace un profesor? } \\
\text { Preguntas sobre la casa: } \\
\text { ¿Para ti qué significa tu casa? } \\
\text { ¿Qué es lo que más disfrutas hacer en la casa? } \\
\text { ¿Qué es lo que menos te gusta hacer en la casa? } \\
\text { ¿Qué actividades realizas con frecuencia en tu } \\
\text { casa? (Enumera las } 5 \text { más recurrentes) } \\
\text { ¿Quiénes viven en tu casa? (Papá, mamá, } \\
\text { hermano...) } \\
\text { Sobre ti (referentes): } \\
\text { ¿Cuándo salgas del colegio a quién te quieres } \\
\text { parecer?, ¿por qué? }\end{array}$ \\
\hline
\end{tabular}




\begin{tabular}{|l|l|}
\hline & $\begin{array}{l}\text { ¿Cuándo salgas del colegio a quién no te quieres } \\
\text { parecer?, ¿por qué? } \\
\text { Si pudieras... ¿Qué quisieras comprar? }\end{array}$ \\
\hline Observación: & $\begin{array}{l}\text { Durante el acercamiento a la Institución Educativa } \\
\text { Camino de Paz, se replanteó realizar esta } \\
\text { actividad, debido a que podía ser complejo para } \\
\text { los niños diligenciar dicha información por escrito. } \\
\text { Bajo esta sugerencia se redefine abordar las } \\
\text { preguntas a través del diálogo con los niños } \\
\text { durante el desarrollo de las otras actividades. }\end{array}$ \\
\hline
\end{tabular}

Ficha 4: Actividad para educadores 1.

\begin{tabular}{|l|l|}
\hline Nombre de la actividad: & Creación de historias \\
\hline Público: & Educadores \\
\hline Objetivo: & $\begin{array}{l}\text { Esta herramienta tiene como base uno de los } \\
\text { materiales educativos del Programa Félix y } \\
\text { Susana llamado No más abusos, que consiste en } \\
\text { contar historias de abuso o violencia infantil a } \\
\text { través de historias ilustradas en cinco cartones. } \\
\text { Se recurre al uso de esta herramienta porque es } \\
\text { el punto de partida para escuchar a los docentes, } \\
\text { es una excusa para generar conversaciones a } \\
\text { partir de sus historias. }\end{array}$ \\
\hline Metodología: & $\begin{array}{l}\text { Se le entregan a cada docente cinco cartones en } \\
\text { blanco y se les da las indicaciones para que } \\
\text { dibujen y/o escriban una historia. Cada cartón } \\
\text { corresponde a una escena. } \\
\text { Deben elegir el escenario de la historia entre: } \\
-\quad \text { La escuela: el salón, el comedor, el } \\
\text { baño... }\end{array}$ \\
& $\begin{array}{l}\text { Lugar del barrio: la tienda, el parque... } \\
\text { Tema: Representación de un conflicto } \\
\text { Una situación que se repite con frecuencia } \\
\text { La propuesta busca resolver la pregunta: ¿Qué } \\
\text { ocurre en la escuela que no estamos viendo? }\end{array}$ \\
\hline
\end{tabular}

Ficha 5: Actividad para educadores 2

\begin{tabular}{|l|l|}
\hline Nombre de la actividad: & Entrevista semi_estructurada individual \\
\hline Público: & Docentes \\
\hline Objetivo: & Profundizar sobre la percepción del docente \\
\hline Metodología: & $\begin{array}{l}\text { Esta es una entrevista a profundidad con los } \\
\text { docentes sobre su vida profesional y la vida de la } \\
\text { escuela. }\end{array}$ \\
\hline
\end{tabular}




\section{Preguntas base:}

- Información básica del entrevistado:

Nombre, edad, lugar de nacimiento, lugar de residencia...

- Formación y experiencia académica y profesional

- Tiempo que lleva trabajando en la institución

- Sobre el contexto donde se ubica la I.E.: ¿Cómo es el acceso a la institución educativa? (describa recorrido, transportes, tiempo estimado para llegar a la institución desde un punto central)

- ¿El barrio se caracteriza por algo?

- ¿Cuál fue la primera impresión al llegar allí?

- ¿QQué caracteriza a los niños de este sector?

- ¿Qué caracteriza a los padres de familia?

- ¿Qué características debe tener un docente de esta institución?

- ¿Qué les ha costado más a los niños sobre los temas del Programa?

- ¿Qué te ha costado más como docente?

- ¿Cuáles son las preguntas más recurrentes de la comunidad educativa respecto a los temas que aborda el Programa?

- ¿Para ti qué significa la escuela?

- ¿Qué deben tener en cuenta este tipo de Programas en su implementación?

- ¿QQué no estamos viendo?

- La institución tiene algún tipo de ritual, tradición.

- Alguna experiencia a resaltar. 


\section{B. Anexo: Cronograma del trabajo de campo}

Ficha 6: Desarrollo de actividades

\begin{tabular}{|l|l|l|}
\hline Actividad & Fecha & $\begin{array}{l}\text { Número de } \\
\text { participantes }\end{array}$ \\
\hline $\begin{array}{l}\text { Medellín. Actividad de } \\
\text { creación de historias con } \\
\text { docentes líderes del } \\
\text { Programa }\end{array}$ & Septiembre 2016 & $\begin{array}{l}\text { Siete docentes } \\
\text { mujeres }\end{array}$ \\
\hline $\begin{array}{l}\text { Medellín. Entrevista } \\
\text { individual a docentes líderes }\end{array}$ & Septiembre 2016 & $\begin{array}{l}\text { Cinco docentes } \\
\text { mujeres }\end{array}$ \\
\hline $\begin{array}{l}\text { Medellín. Cartografía social } \\
\text { con niños entre los 8 y 12 } \\
\text { años }\end{array}$ & Septiembre 2016 & $\begin{array}{l}\text { Tres niñas y cuatro } \\
\text { niños }\end{array}$ \\
\hline $\begin{array}{l}\text { Medellín. Actividad de } \\
\text { creación de historias con } \\
\text { niños entre los 7 y 9 años }\end{array}$ & Septiembre 2016 & $\begin{array}{l}\text { Cuatro niñas y dos } \\
\text { niños }\end{array}$ \\
\hline $\begin{array}{l}\text { San Basilio de Palenque. } \\
\text { Actividad de creación de } \\
\text { historias con docentes } \\
\text { líderes del Programa }\end{array}$ & Noviembre de 2016 & $\begin{array}{l}\text { Tres mujeres y un } \\
\text { hombre }\end{array}$ \\
\hline $\begin{array}{l}\text { San Basilio de Palenque. } \\
\text { Entrevista individual a } \\
\text { docentes líderes }\end{array}$ & Noviembre de 2016 & $\begin{array}{l}\text { Tres mujeres y un } \\
\text { hombre }\end{array}$ \\
\hline $\begin{array}{l}\text { San Basilio de Palenque. } \\
\text { Cartografía social con niños } \\
\text { entre los 8 y 12 años }\end{array}$ & Noviembre de 2016 & Dos niñas y dos niños \\
\hline $\begin{array}{l}\text { San Basilio de Palenque. } \\
\text { Actividad de creación de } \\
\text { historias con niños entre los } \\
\mathbf{7} \text { y 9 años }\end{array}$ & Noviembre de 2016 & Seis niñas y un niño \\
\hline
\end{tabular}




\section{Bibliografía}

Acevedo, J. (2014). El estudio del territorio a través de un semillero de investigación en educación para las ciudadanías (tesis de maestría). Universidad de Antioquia, Medellín, Colombia

Aristizábal, S. (2000). La diversidad étnica y cultural de Colombia: un desafío para la educación. Pedagogía y Saberes (15), 61-68

Beltrán, L. (2010). Comunicación para la salud del pueblo. Una revisión de conceptos básicos. Red de Estudios sobre Culturas Contemporáneas

Bolívar, C. (2010). Justificaciones morales de los niños y niñas acerca de la sexualidad. Revista Latinoamericana de Ciencias Sociales, Niñez y Juventud, 8 (2), 1013-1023. Recuperado de: http://www.scielo.org.co/pdf/rlcs/v8n2/v8n2a17.pdf

Clifford, J. (2001). Dilemas de la cultura. Antropología, literatura y arte en la perspectiva posmoderna. Barcelona: Gedisa editorial

Corporación Gilania. (2009, 2010 y 2011). Documentos no publicados, información para uso de la Fundación SURA

Cortez, N. (2015). Interculturalidad, diferencia y etnoeducación: la educación como lugar antropológico. Medellín: Ediciones UNAULA

Cuadros, I., Ordóñez, M. (2006). La infancia rota. Testimonios y guías para descubrir y tratar el abuso sexual infantil. Bogotá: Grupo Editorial Norma

Díaz, E. (2015). Reflexiones pedagógicas sobre la formación de docentes en los estudios escolares afrocolombianos. Revista Colombiana de Educación (69), 183-202. Recuperado de: http://revistas.pedagogica.edu.co/index.php/RCE/article/view/3281/2845

Escalante, A. (1979). El Palenque de San Basilio. Una comunidad de descendientes de negros cimarrones. Barranquilla: Editorial Mejoras 
Flores, M. (2007). La identidad cultural del territorio como base de una estrategia de desarrollo sostenible. Revista Ópera (7), 35-54

Freire, P. (2011). La educación como práctica de la libertad. México: Siglo XXI

Friedemann, Nina S. de. \& Patiño, C. (1983). Lengua y sociedad en el palenque de San Basilio. Bogotá: Instituto Caro y Cuervo

Fundación SURA. (2016). Vivir la confianza. Informe de Gestión 2016

Gómez, A. \& Acosta W. A. (2006). Diversidad cultural en la formación de maestros. Bogotá: Universidad Pedagógica Nacional

Guber, R. (2001). La etnografía: método, campo y reflexividad. Bogotá: Grupo Editorial Norma

Gumucio-Dagron, A. (2010). Cuando el doctor no sabe. Comentarios críticos sobre promoción de la salud, comunicación y participación. Estudios sobre las Culturas Contemporáneas. XVI, (31), 67-93. Recuperado de http://www.redalyc.org/articulo.oa?id=31613952003

Gutiérrez, A. (2009). Ciudadanía y Territorio: Escenario para la Formación Ciudadana. Revista Palobra. (10), 109-127

Hoyos, J. (2003). Escribiendo historias. El arte y el oficio de narrar en el periodismo. Medellín: Editorial Universidad de Antioquia

Kaplún, M. (2001). A la Educación por la Comunicación. La práctica de la Comunicación Educativa. Quito: Ediciones CIESPAL, segunda edición

Longás, J., Civís, M., Riera, J., Fontanet, A., Longás, E., Andrés, T. (2008). Escuela, educación y territorio. La organización en red local como estructura innovadora de atención a las necesidades socioeducativas de una comunidad. Pedagogía Social. Revista Interuniversitaria, (15), 137-151. Recuperado de http://www.redalyc.org/articulo.oa?id=135012674011 
Mojica, J. A. (2011, 18 de agosto). Palenque, un pueblo tejido en trenzas. Periódico El Tiempo. Recuperado de: http://www.eltiempo.com/archivo/documento/CMS$\underline{10180608}$

Monsalve, C. (2014, 10 de enero). Barrio de Medellín recibió premio internacional. Periódico El Tiempo. Recuperado de: http://www.eltiempo.com/archivo/documento/CMS-13350279

Naranjo, G. (1992). Medellín en zonas. Medellín: Corporación Región

Organización de las Naciones Unidas para la Educación, la Ciencia y la Cultura. (2017). El espacio cultural de Palenque de San Basilio. Recuperado de: https://ich.unesco.org/es/RL/el-espacio-cultural-de-palenque-de-san-basilio-00102

Posso, P., Sepúlveda, M., Navarro, N. \& Laguna, C. E. (2015). La lúdica como estrategia pedagógica para fortalecer la convivencia escolar. Lúdica Pedagógica, 2 (21). 163174. Recuperado de: $\underline{\text { https://dialnet.unirioja.es/servlet/articulo?codigo }=5401571}$

Restrepo, A. (2017, 29 de junio). Cartagena: De pobrezas y riquezas (una mirada desde la cultura, las artes y la educación). Periódico El Espectador. Recuperado de: http://www.elespectador.com/opinion/cartagena-de-pobrezas-y-riquezas-una-miradadesde-la-cultura-las-artes-y-la-educacion-columna-700597

Ríos, A. (2014). Percepciones de los sujetos en situación de vulnerabilidad sobre el territorio y la relación con el derecho a la educación, en la vereda Granizal (Bello Antioquia) (tesis de especialización). Universidad de Antioquia, Medellín, Colombia

Robles, M. (1996). Prensa y educación para la salud en la escuela. Revista Comunicar 6: La televisión en las aulas. 3, 94-99

Rodríguez, D. (2010). Territorio y territorialidad. Nueva categoría de análisis y desarrollo didáctico de la Geografía. Uni-pluri/versidad.10 (3). Recuperado de http://aprendeenlinea.udea.edu.co/revistas/index.php/unip/article/view/9582/8822 
Rojas, J. (2010). Semblanza y aportes metodológicos de un investigador social: Orlando Fals Borda. Ponencia presentada al Simposio Internacional de Investigadores en Ciencias Sociales. Universidad de Antioquia, Medellín, 1-15

Romero, O. L., Vaca, M. P., Galindo, M. J. \& Sierra, S. (2016). Comunicación verbal y no verbal en una institución educativa distrital y su relación con los procesos de convivencia escolar. Actualidades Pedagógicas, (68), 87-111. doi: http://dx.doi.org/10.19052/ap.3666

Sánchez, A. P. \& Restrepo, M. (2014). El entorno social como factor determinante de la convivencia escolar. Revista Gestión y Región (18), 67-81. Recuperado de: http://biblioteca.ucp.edu.co/OJS/index.php/gestionyregion/article/view/2745/2703

Uribe, F. (director y productor). (2014). La Casa Pintada, Palenque de Colores [Documental]. Colombia: Telemedellín

Velásquez, L. M. \& Horta, O. W. (s.f.). De la mano con Félix y Susana. Colombia: Propiedad Pública. Recuperado de: http://www.propiedadpublica.com.co/de-la-manocon-felix-y-susana

Walsh, C. (2007). Interculturalidad, colonialidad y educación. Revista Educación y Pedagogía. XIX, (48), 25-35 